\author{
PIOTR SKOWROŃSKI \\ https://orcid.org/0000-0001-8228-2790 \\ Instytut Historii PAN, Warszawa \\ Muzeum Łazienki Królewskie
}

\title{
ZMAGANIA O KSZTAŁT OSOBOWY SEJMU 1773-1775*
}

\begin{abstract}
Abstrakt: Artykuł stanowi uzupełnienie dotychczasowej wiedzy na temat kampanii przedsejmowej z roku 1773. Wykorzystanie relacji dyplomatów mocarstw rozbiorowych oraz rozproszonych źródeł krajowych pozwala na lepsze rozpoznanie sił politycznych w okresie I rozbioru Rzeczypospolitej oraz na większe docenienie zaangażowania politycznego osób, którym dotychczasowa historiografia przypisywała bierną postawę.
\end{abstract}

Słowa kluczowe: Rzeczpospolita Obojga Narodów, I rozbiór Polski, konfederacja barska, sejm 1773-1775, Stanisław August.
Abstract: The article is a contribution to knowledge of the parliamentary election campaign in 1773. An analysis of reports by diplomats of the partitioning powers and dispersed Polish sources allows for better identification of political forces active during the first partition of the Commonwealth and fuller appreciation of the political involvement of people with a passive attitude attributed to them in the scholarly literature on the subject.

Keywords: Polish-Lithuanian Commonwealth, first partition of Poland, Bar Confederation, Sejm of 1773-75, King Stanisław August.

Pierwszy rozbiór Rzeczypospolitej jest nęcącym zagadnieniem badawczym ze względu na bezprecedensowy charakter przejęcia znacznej części terytorium dużego europejskiego państwa i wiążące się z tym zagadnienia prawne, polityczne, militarne, społeczne czy nawet moralne.

* Pani Zofii Zielińskiej dziękuję za godziny inspirujących rozmów i ważne wskazówki warsztatowe, które otrzymałem, pisząc ten tekst. Serdecznie dziękuję za pomoc także: Dorocie Dukwicz, Małgorzacie Mrugale-Achahboune oraz Andrzejowi Haratymowi. 
Temat ten, na co zwracał uwagę Jerzy Michalski prawie pół wieku temu, posiada obfitą literaturę obcojęzyczną, przy zadziwiającej szczupłości opracowań historiografii polskiej. Dziś wydarzenia lat siedemdziesiątych XVIII w., wciąż budzące żywe emocje, zaczynają być coraz częściej obecne w polskim dyskursie naukowym ${ }^{1}$.

Badacz dziejów politycznych okresu bezpośrednio poprzedzającego obrady sejmu rozbiorowego (rozpoczętego 19 kwietnia 1773 r.) boryka się z ubogą bazą źródłową. W niepewnej sytuacji politycznej przełomu lat 1772-1773 szlachta znacząco ograniczyła korespondencję ${ }^{2}$. Pomimo to, zestawienie szczątkowej korespondencji oraz relacji dyplomatów państw zaborczych pozwala odtworzyć działania polityczne towarzyszące kampanii sejmikowej $1773 \mathrm{r}$. Skłoniło mnie to do podjęcia jeszcze raz tematu, obecnego już, co prawda, w polskiej historiografii ${ }^{3}$.

Śledząc pierwsze miesiące 1773 r. (od rady senatu, rozpoczętej 8 lutego 1773 r., do początku sejmu delegacyjnego), spróbuję odpowiedzieć na pytania zadawane już przez naocznych świadków rozbioru:

czy sejm ten może zostać złożony legalnie? Czy trzy mocarstwa rozbiorowe zezwolą na odbycie sejmików na terenach, które objęły w posiadanie? Czy osoby, które są obecnie traktowane jako poddani tych mocarstw,

${ }^{1}$ Rezygnuję z przedstawienia całej historiografii pierwszego rozbioru. Obszernie na ten temat: J. Michalski, Historiografia polska wobec problematyki pierwszego rozbioru, w: idem, Studia historyczne z XVIII i XIX wieku, t. 2: Ideologia, nauka, historiografia, [red. nauk. W. Kriegseisen, Z. Zielińska], Warszawa 2007, s. 496-508. Uzupełnienia: D. Dukwicz, Kilka słów na temat historiografii pierwszego rozbioru, w: W. Konopczyński, Pierwszy rozbiór Polski, [red. Z. Zielińska], Kraków 2010, s. XLVII-LI; eadem, Rosja wobec sejmu rozbiorowego warszawskiego (1772-1775), Warszawa 2015, s. 12-28.

${ }^{2}$ Chociaż nie dysponujemy badaniami na ten temat, to widoczne są przerwy w zwodach korespondencji szlacheckiej. Tak dzieje się z korespondencją Łopacińskich w LVIA (fond 1135). Kwerenda dotycząca sejmików poselskich 1773 r. w obfitej korespondencji Sapiehów w Bibliotece im. E. i E. Wróblewskich Litewskiej Akademii Nauk (fond 139) także przyniosła negatywne skutki. Na znaczeniu traci też wówczas korespondencja marszałka nadwornego koronnego Jerzego Wandalina Mniszcha (BC 3869). Niemal żadnych listów dotyczących kampanii sejmikowej nie odnajdziemy w tzw. korespondencji krajowej Stanisława Augusta w BC w tomach, których ramy chronologiczne odpowiadają interesującemu nas zagadnieniu (m.in. sygn. 654, 656-660, 662, 665, 667, 668, 670, 672, 675-677, 679, 680, 682, 684, 685, 690, 692, 693, 710).

${ }^{3}$ Na temat sejmików poselskich 1773 przede wszystkim: W. Konopczyński, Geneza i ustanowienie Rady Nieustajacej, Kraków 1917, s. 194-196; idem, Konfederacja barska, t. 2 , Warszawa 1991, s. 706-707; idem, Pierwszy rozbiór, s. 189-190; J. Michalski, Rejtan i dylematy Polaków $w$ dobie pierwszego rozbioru, w: idem, Studia historyczne z XVIII $i$ XIX wieku, t. 1: Polityka i społeczeństwo, [red. nauk. W. Kriegseisen, Z. Zielińska], Warszawa 2007, s. 174-187; D. Dukwicz, Rosja, s. 153-178. 
będą mogły uczestniczyć w sejmie jako senatorowie i posłowie? A jeśli wezmą oni udział w obradach, czy będą mogli być traktowani jako niezależni? Czy sejm okrojony o te osoby będzie uznany za legalny? [--] Czy może intencją mocarstw, które muszą zdawać sobie sprawę z wszystkich tych trudności, jest podzielić pozostałą część Polski i wymazać ją z liczby państw? ${ }^{4}$

Ponadto chciałbym odpowiedzieć na pytania, jakie osoby wykorzystywał dwór warszawski oraz dyplomaci mocarstw sąsiadujących z Rzecząpospolitą do przeforsowania swoich kandydatów na posłów oraz jakie były oczekiwania tych dyplomatów wobec sejmików wyznaczonych na 22 marca.

18 września 1772 r. posłowie Rosji Otto Magnus von Stackelberg i Prus Gédéon Benoît notyfikowali polskiemu ministerium rozbiór, żądając zwołania sejmu, który zaakceptowałby pretensje terytorialne zaborców5. Dwór warszawski pięć dni później (22 IX) stanowczo odrzucił żądania mocarstw, pomijając przy tym kwestię zwołania sejmu. Od 6 do 15 października 27 obecnych w Warszawie senatorów brało udział w radzie senatu, wspierając Stanisława Augusta w wypracowywaniu planu działań. Zgodnie z propozycjami biskupa kujawskiego Antoniego Ostrowskiego zdecydowali, aby ponownie odrzucić roszczenia zaborców, upoważnić króla do wysłania zagranicznych poselstw oraz wydania manifestów sprzeciwiających się zmuszaniu mieszkańców terenów objętych rozbiorem do składania przysięgi nowym władcom. Podjęto także decyzję o zwołaniu plenarnej rady senatu. Stanowiła ona krok niezbędny do zwołania sejmu, na którym tak bardzo zależało mocarstwom ościennym. Zgodnie z praktykowaną w tym czasie przez Stanisława Augusta polityką odwlekania decyzji i demonstrowania oporu, postanowienia październikowej rady senatu nie zawierały konkretnej daty przyszłych obrad senatus consilium. Jednak na skutek gróźb Stackelberga Stanisław August

4 „But how is this Diet to be legally composed? Will the three powers permit the Diet to be hold in the provinces, whereof they have respectively taken possession? Will they permit the people whom they now consider as their subjects to assist at it as senators or nuntios? Or, if they do come, can they be called free? Will the Diet curtailed of those members to be a legal one? [--] Or is it the intention of those powers, who certainly must know all those difficulties and incongruities, to divide the remaining part of Poland also and annihilate the very name of it?", T. Wroughton do lorda Suffolk, 26 X 1772, BC 1984, k. 435v.

${ }^{5}$ Stackelberg, według zaleceń swego dworu, miał ogłosić w Warszawie rozbiór najpóźniej 18 września 1772 r. Audiencja odbyła się bez udziału austriackiego dyplomaty, Karla Revickiego, który specjalnie opóźnił przyjazd do Warszawy, T.E. Modelski, Wywód ks. Kaunitza z r. 1772 o pierwszym podziale Polski, KH 31, 1917, 1, s. 72-74. 
zdecydował się wyznaczyć termin ${ }^{6}$. Zaproponowany przez monarchę dzień 1 marca 1773 r. spotkał się z niezadowoleniem dyplomatów, którzy ostatecznie wymusili zmianę daty na 8 lutego ${ }^{7}$.

Dla lepszego zrozumienia wydarzeń z przedwiośnia 1773 r. należy przyjrzeć się scenie politycznej w Rzeczypospolitej w momencie notyfikacji rozbioru. Stanisław August wkraczał w rok 1773 ze słabym zapleczem politycznym, gdyż „stronnictwa regalistycznego właściwie nie było". Czartoryscy zachowywali wymuszoną przez Rosję polityczną bierność ${ }^{9}$. Król, pozbawiony wsparcia wujów i ich klienteli, musiał ostrożnie poszukiwać osób, z którymi mógłby współpracować podczas zbliżającego się sejmu. Zarówno monarcha, jak i szukający współpracowników Stackelberg stanęli do walki o pozyskanie jak największej liczby przedstawicieli średniej szlachty. Kierujący rosyjską polityką zagraniczną Nikita Panin zalecał posłowi, aby współpracował z osobami posiadającymi autorytet w społeczeństwie, jednocześnie pozwalał mu przyjąć pod swoje skrzydła wszystkich zainteresowanych (z wyjątkiem Czartoryskich). Do łask mogli powrócić nawet niegdysiejsi konfederaci barscy, za cenę ślubowania wierności królowi oraz imperatorowej. Stackelberg starał się pozyskać byłych barzan poprzez zapewnienia o przyjaźni dworu petersburskiego, wiedząc, że ekskonfederatom łatwiej będzie wyzbyć się niechęci do Rosji niż nienawiści do Stanisława Augusta ${ }^{10}$. Do czasu stworzenia prorosyjskiego stronnictwa poseł korzystać miał z osób skupionych wokół poprzednika, Kaspara von Saldern ${ }^{11}$. Panin wskazał, że przydatni mogą okazać się także prymas Gabriel Podoski, podskarbi koronny Teodor Wessel i marszałek nadworny koronny Franciszek Wielopolski ${ }^{12}$.

${ }^{6}$ J. Michalski, Rejtan i dylematy, s. 167. Groźby, którymi posługiwał się Stackelberg w rozmowie ze Stanisławem Augustem 6 listopada 1772 r., to poszerzenie zaborów, detronizacja, spustoszenie dóbr państwowych przez wojska oraz pozbawienie króla majętności „aż do ostatniej łyżki”, Stanisław August do J.A. Moneta, 11 XI 1772, Stanisław Poniatowski i Maurycy Glayre. Korespondencja dotycząca rozbiorów Polski, cz. 1, wyd. E. Mottaz, Warszawa 1901, s. 101.

${ }^{7}$ J. Michalski, Rejtan i dylematy, s. 169.

8 Ibidem, s. 182.

9 Ibidem, s. 166.

10 Poseł rosyjski prosił Panina o blankiety dokumentów, które mógłby własnoręcznie uzupełnić i wręczać osobom ponownie nawiązującym współpracę z ambasadą rosyjską, W. Konopczyński, Pierwszy rozbiór, s. 130.

${ }^{11}$ D. Dukwicz, Rosja, s. 59-62. Za Konopczyńskim (Geneza, s. 156-157) jako współpracowników Salderna identyfikuję: kuchmistrza koronnego Adama Ponińskiego, Antoniego Ostrowskiego, kasztelana gostyńskiego Antoniego Lasockiego, pisarza wielkiego koronnego Kazimierza Raczyńskiego, biskupa poznańskiego i kanclerza wielkiego koronnego Andrzeja Młodziejowskiego oraz kasztelana poznańskiego Józefa Mielżyńskiego.

12 D. Dukwicz, Rosja, s. 67. 
Rada senatu, w której udział wzięło 30 senatorów (a zatem zaledwie o trzech więcej niż w październiku), rozpoczęła obrady 8 lutego 1773 r. ${ }^{13}$ Uczestnicy zdawali sobie sprawę, że ich celem jest „złożenie lub nie sejmu, o który mocni sąsiedzi nalegają"14. Ze względu na tematykę obrad oraz obawy o bezpieczeństwo osobiste i majątkowe senatorowie masowo uchylali się od udziału w radzie. W listach, które przysyłali do kancelarii koronnej, wymawiali się przede wszystkim stanem zdrowia. $\mathrm{O}$ dyspensę z uczestnictwa w senatus consilium wystarali się m.in.: wojewoda podlaski Jan Zamoyski, kasztelan zawichojski Aleksander Romer, kasztelan bydgoski Ignacy Kościelski, kasztelan sandomierski Maciej Sołtyk, wojewoda brzesko-kujawski Ludwik Dąmbski ${ }^{15}$. Jak najliczniejsze zgromadzenie senatorów leżało jednak w interesie mocarstw rozbiorowych. Obrady dużej reprezentacji senatu, a w przyszłości i licznie obsadzonego sejmu, który udzieliłby zgody na cesje terytorialne, wzmacniałyby pozory legalności rozbioru. Ambasadorowie liczyli na przyjazd do Warszawy przebywającego w Gdańsku prymasa Podoskiego, współpracującego z ambasadą rosyjską od lat sześćdziesiątych. Jego przyjazd wydawał się o tyle ważny, że - zgodnie z przewidywaniami Benoît w episkopacie tylko on oraz biskup wileński Ignacy Massalski nie byli przeciwnikami wprowadzenia forsowanego przez Rosję politycznego i religijnego równouprawnienia niekatolików, która to sprawa miała po raz kolejny stanąć na sejmie ${ }^{16}$. Massalski pozytywnie odpowiedział na propozycję współpracy i za namową Stackelberga wrócił do kraju pod koniec 1772 r. ${ }^{17}$ Podoski zaś, wezwany listem okólnym Stanisława Augusta, odpowiedział monarsze uszczypliwościami. Kwestionował królewskie zapewnienia o swobodnych obradach senatus consilium, gdy sam monarcha zdradzał, że termin zgromadzenia wymusili zagraniczni dyplomaci. Kpił też z zapewnień o bezpieczeństwie senatorów, skoro król sam nie jest bezpieczny, czego dowodem zamach z listopada $1771 \mathrm{r}^{18}$

13 Spis uczestników rady senatu, Stanislas Auguste, Mémoires, wyd. A. Grześkowiak-Krwawicz, D. Triaire, Paris 2012, s. 443-444 (dalej: Mémoires).

${ }^{14}$ A. Młodziejowski do kasztelanowej kaliskiej H. Zbijewskiej, 8 II 1773, AGAD, Varia Oddziału I (dalej: AGAD, Varia) 15, s. 29.

15 Ibidem, s. 31-41. Kanclerz wielki koronny Andrzej Młodziejowski zapewniał pisemnie niektórych z nich, że za nieobecność nie spotka ich żadna kara.

16 G. Benoît do Fryderyka II, 17 III 1773, Geheimes Staatsarchiv, Preussischer Kulturbesitz, Hauptabteilung 1, Repositur 96 (Geheimes Kabinett, ältere Periode) (dalej: GStA PK, 1 HA Rep.), nr 52e. O zabiegach posła pruskiego: D. Dukwicz, Rosja, s. 137-138.

17 Biskup wileński przebywał na emigracji od czasów Salderna, kiedy to Rosjanie wykryli jego kontakty z przywódcą konfederacji na Litwie, Michałem Kazimierzem Ogińskim, I. Szybiak, Ignacy Jakub Massalski, PSB, t. 20, Wrocław-Warszawa-Kraków 1975, s. 136.

${ }^{18}$ Kopia listu G. Podoskiego do Stanisława Augusta, 29 I 1773, BJ 6674, s. 11-13. „Le primat n'a point apparu. Il a, au contraire, fait la response ci-jointe à la lettre circulaire 
Możliwość powrotu uzyskał także Wessel, jeden z głównych przywódców konfederacji barskiej. Zachęcony listami Stackelberga, przyjechał do Warszawy na początku stycznia 1773 r. ${ }^{19}$ i z miejsca zażądał od króla wypłaty zaległych 300 tys. zł pensji. Mimo pustki w skarbie, wsparty przez Stackelberga podskarbi ponoć wymusił to, czego pragnął ${ }^{20}$. Pod koniec stycznia 1773 r. biskup poznański i kanclerz wielki koronny Andrzej Młodziejowski podjął próbę mediacji między królem a podskarbim. Starał się on nakłonić Stanisława Augusta do przyjęcia Wessla na audiencji w prywatnych pokojach monarchy, jednocześnie sugerując ostrożność i negatywnie oceniając jego republikańskie poglądy ${ }^{21}$. Biskup poznański przyjmował jednak za dobrą monetę deklarację podskarbiego, że podczas sejmu będzie konsultował swoje działania $\mathrm{z}$ nim oraz monarchą.

Senatorowie, których godności związane były z ziemiami oderwanymi od Rzeczypospolitej, otrzymali od posłów państw rozbiorowych zakaz uczestnictwa w radzie. Największym ciosem dla króla było wydanie zakazu wojewodzie ruskiemu, księciu Augustowi Aleksandrowi Czartoryskiemu ${ }^{22}$. Podobnie postąpiono m.in. z wojewodą witebskim Józefem Antonim Sołłohubem ${ }^{23}$ i biskupem inflanckim Janem Stefanem Giedroyciem.

du roi, qui prouve également combien de chimères il règne encore dans les têtes polonoises. Le ministre de Russie et moi avions fait exhorter le primat de se rendre à Varsovie, je lui avois même écrit là-dessus, mais il m'a repondu, qu'outre que ma lettre lui étoit parvenu trop tard, il lui sembloit que les inconvénients chagrinans dont je lui parlois et le malheur personnel, étoient plus supportables que la seule idée de prêter les mains à tout ce qui ne pourroit pas être salutaire à Sa Patrie, à laquelle dans ce moment sa présence ne pouvoit être d'aucune utilité", G. Benoît do Fryderyka II, 10 II 1773, GStA PK, 1 HA Rep. 96, nr 52e. Zdaniem Benoît negatywne nastawienie prymasa wynikało z podszeptów rezydenta francuskiego w Gdańsku (Josepha Mathiasa Gérarda de Rayneval). Podoski miał nawet rozrzucać po Gdańsku jakieś pisemka o planowanych przez Stanisława Augusta rządach absolutnych, J. Michalski, Rejtan i dylematy, s. 177.

${ }^{19}$ Korespondencja Wessla z okresu odsuwania się podskarbiego od dogorywającej konfederacji w BK 2182; W. Konopczyński, Konfederacja barska, t. 2, s. 671-672.

20 „Wiadomości z Warszawy dn. 7 stycznia 1773”, BJ 6674, s. 1. Ustanowienie pensji dla Wessla na sejmie 1767/8, VL 7, s. 307.

${ }^{21}$ „Poznałem, że nabity jest czyli insynuacyjami sąsiedzkimi, czyli jeszcze robotą delegacyjną co do liberum veto ad materias status", A. Młodziejowski do Stanisława Augusta, 29 I 1773, BC 799, k. 69-70.

${ }^{22}$ J. Michalski, Rejtan i dylematy, s. 175-176. „Książę jegomość wojewoda ruski, znajdując się w bezczynności, wybiera się z Warszawy do Puław na mieszkanie”, J.N. Chęcki do A. Chmary, 22 II 1773, BJ 6666, k. 186.

${ }^{23}$ Kopie listu O. Stackelberga do J.A. Sołłohuba w tłumaczeniu na j. polski, 4 II 1773, BJ 6674, s. 64-64 oraz Lwowska Narodowa Naukowa Biblioteka Ukrainy im. Wasyla Stefanyka (dalej: LNNBU) 571, s. 130. Obecność tego listu w dwóch znanych mi sylwach wskazuje, że Sołłohub rozpropagował go, chcąc pokazać skalę nieprawości i przemocy, które dotknęły Rzeczpospolitą. Mimo tego wojewoda wrócił do polityki. Na sejmie 
Ten ostatni demonstracyjnie pojawił się jednak na radzie senatu, ulegając dopiero perswazjom króla, aby nie narażał się bez potrzeby ${ }^{24}$. Pruscy urzędnicy w Malborku wystawili zakaz uczestnictwa w radzie kasztelanowi gostyńskiemu Antoniemu Lasockiemu, którego dobra znalazły się za kordonem. Zakaz został cofnięty po interwencji Benoît, który słusznie uznawał kasztelana za jednego z najwierniejszych stronników rosyjskich ${ }^{25}$.

Chęć przyjazdu na walne senatus consilium wyraził kasztelan bełski Ewaryst Andrzej Kuropatnicki. Już pod koniec 1772 r. prosił Młodziejowskiego, aby wyjednał mu zgodę posłów państw rozbiorowych na uczestnictwo w obradach ${ }^{26}$. Gubernator Galicji generał Johann Pergen wydał bowiem wojskom na pograniczu zakaz wypuszczania senatorów zza kordonu. Samowolny wyjazd miał skutkować konfiskatą majątku ${ }^{27}$. Mimo że w styczniu Kuropatnicki otrzymał pomyślne wiadomości od Młodziejowskiego, wojsko austriackie nie dopuściło do jego wyjazdu. Z tego powodu do Warszawy nie przyjechał też kasztelan wiślicki Franciszek Kochanowski, a kasztelan sądecki Stanisław Ankwicz został zawrócony z drogi ${ }^{28}$.

W senatus consilium nie wzięła też udziału najtęższa głowa konfederacji barskiej - biskup kamieniecki Adam Krasiński. Porwany 2 października 1772 r. przez rosyjskich żołnierzy, przebywał do grudnia tego roku w Warszawie. Stackelberg liczył na jego współpracę podczas sejmu i przy ostatecznym wyciszeniu konfederacji. Szybko przekonał się, że biskup nie zamierzał podjąć żadnej działalności, stawiając jako warunek sine qua non detronizację Stanisława Augusta. Po podpisaniu odpowiednich zobowiązań Krasiński otrzymał zgodę na swobodne poruszanie się po kraju i wyjechał na Podole ${ }^{29}$. Wojewoda gnieźnieński August Sułkowski,

wszedł w skład komisji emfiteutycznej, a Katarzyna II „w nagrodę zasług” pozwoliła mu zachować jego białoruskie dobra, P.P. Romaniuk, Sołłohub Józef Antoni, PSB, t. 40, Warszawa-Kraków 2000-2001, s. 321.

${ }^{24}$ Mémoires, s. 443. Stackelberg miał go straszyć zesłaniem, P. Ugniewski, Media i dyplomacja. „Gazette de France” o sejmie rozbiorowym 1773-1775, Warszawa 2006, s. 26.

${ }^{25}$ D. Dukwicz, Rosja, s. 132.

${ }^{26}$ E. Kuropatnicki do A. Młodziejowskiego, 23 XII 1772, LNNBU 571, s. 67-68.

27 E. Kuropatnicki do A. Młodziejowskiego, 28 I 1773, ibidem, s. 94.

${ }_{28}$ A. Młodziejowski do E. Kuropatnickiego, 21 I 1773, ibidem, s. 99; E. Kuropatnicki do A. Młodziejowskiego, 4 II 1773, ibidem, s. 99-100; tamże mowa, którą kasztelan bełski miał wygłosić na radzie senatu. Kanclerz przyjął wytłumaczenie nieobecności na obradach senatu, skoro mu „przemoc bytności zabroniła”, A. Młodziejowski do S. Ankwicza, 10 II 1773, AGAD, Varia, 15, s. 32.

${ }^{29}$ W. Szczygielski, Krasiński Adam, PSB, t. 15, Wrocław-Warszawa-Kraków 1970, s. 164; Informacya biskupa kamienieckiego dana księdzu Pezowi, w: H. Schmitt, Źródła odnoszace się do pierwszego okresu panowania Stanisława Augusta po rok 1773, Lwów 1884, s. $208-211$. 
który później wiódł prym podczas sejmu, również nie przyjechał na walną radę, gdyż, jak deklarował, zajęty był ochroną województw wielkopolskich przed uciskami wojska pruskiego ${ }^{30}$. Natomiast przebywający w Warszawie wojewoda kaliski Ignacy Twardowski słabym zdrowiem wymówił się od podpisania ustaleń rady ${ }^{31}$.

Lutowa rada senatu zgodnie z wolą ambasadorów podjęła decyzję o zwołaniu sejmu. Datę sejmików wyznaczono na 22 marca $1773 \mathrm{r}^{32}$ Tygodniowe obrady senatu nie stały się areną większych rozgrywek politycznych. Reprezentujący Familię marszałek wielki koronny Stanisław Lubomirski wprowadził jedynie do postanowień rady punkty dotyczące osądzenia królobójców i ich mocodawców ${ }^{33}$.

Ekspedycja sejmowa, składająca się z uniwersału przedsejmowego oraz kopii not, które wymieniali posłowie państw rozbiorowych z polskim ministerium, była gotowa 20 lutego. Uniwersał nie zawierał konkretów, które służyłyby jako wskazówki dla instrukcji poselskich, co było notabene charakterystyczne dla czasów stanisławowskich, a w warunkach niepewnej sytuacji politycznej 1773 r. stanowiło wygodny fortel zarówno dla króla, jak i mocarstw rozbiorowych. Jedynie legacja dla królewskich wysłanników na sejmiki zawierała prośbę o potępienie w instrukcjach aktu bezkrólewia i zamachu na króla oraz postulat oddelegowania na sejm osób „znajomością rzeczy i gorliwością obywatelską uprzedzonemi zaleconych i tych umocowanie, żeby wyrwanie Rzpltej z tak opłakanego stanu, w jakim jest, o całości jej granic, jak tylko będzie można, wraz z JKM zaradzali" 34 .

30 A. Sułkowski, Kopia sub data 20 January 1773 responsu xcia Sułkowskiego, wwdy gniezninskiego na list cyrkularny Nayiasn. Króla Jmci pro Senatus Consilio na dzień 8 Febr. 1773 determinowanego, [b.d. i m.w.]; Wiadomości z Warszawy dn. 4 marca, BJ 6674, s. 113; D. Dukwicz, M. Zwierzykowski, Sułkowski August, PSB, t. 45, Warszawa-Kraków 2007-2008, s. 546. August Sułkowski współpracował ze Stackelbergiem od połowy października 1772 r., W. Konopczyński, Geneza, s. 164-169.

${ }^{31}$ P. Skowroński, „Trudno przeciw wodzie płynać”. Ignacy Twardowski w okresie I rozbioru Polski, w: Zmierzch i świt. Stanisław August i Rzeczpospolita 1764-1795, red. A. Antoniewicz, R. Kosińska, P. Skowroński, Warszawa 2015, s. 166. Tamże o nieudanych zabiegach Stackelberga nakłonienia do przyjazdu do Warszawy szefa stronnictwa dworskiego z czasów Augusta III, Jerzego Mniszcha. O „dyplomatycznych chorobach” przebywających w Warszawie senatorów: J. Michalski, Rejtan i dylematy, s. 173.

${ }^{32}$ Uniwersał na sejmik przedsejmowy poselski, Warszawa, 22 II 1773, m.in.: AGAD, Zbiór Popielów 123, k. 30 i AP w Poznaniu, Gr. Poznań 1219, k. 206.

${ }^{33}$ J. Michalski, Rejtan i dylematy, s. 173; W. Ostrożyński, Sprawa zamachu na Stanisława Augusta z 3 listopada 1771 przed sądem sejmowym, Lwów 1891, s. 31-34.

${ }^{34} \mathrm{~J}$. Michalski, Rejtan i dylematy, s. 174. „Instrukcja JKM [--] na sejmik przedsejmowy", m.in.: BPAU-PANKr 320, k. 188 r-v. i LNNBU, 571. Treść uniwersału zgryźliwie komentowała Urszula Lubomirska w liście do Jerzego Mniszcha (14 III 1773): „Mam tu już 
Wydaje się, że część senatorów unikała przykładania ręki do administracyjnych obowiązków w okresie przedsejmikowym. Świadczy o tym przykładowo towarzyszący ekspedycji list kanclerza do biskupa warmińskiego Ignacego Krasickiego: „Ja WXMci o rzecz niepodobną nie proszę, ale z urzędu, co potrzeba, czynię. Jest zaś potrzeba, aby constet, jako ta ekspedycyja doszła do rąk WXMci i jako fecisti nec ne usum [?] jej i tego tylko z miejsca mego dopraszam się" 35 . Krasickiemu angażowanie się w organizację sejmików mogło nie być w smak, gdyż właśnie wrócił z Berlina, gdzie starał się o względy Fryderyka II i zmniejszenie uciążliwości pruskiej okupacji wojskowej w swojej diecezji ${ }^{36}$.

$\mathrm{Na}$ dyplomatach mocarstw rozbiorowych i głównodowodzących wojsk zaborczych w Rzeczypospolitej spoczywała odpowiedzialność za wybór posłów według podziału na trzy strefy wpływów. Stackelberg miał kontrolować sejmiki na Litwie i Wołyniu, Benoît - sejmiki województw rawskiego, łęczyckiego, sieradzkiego, sejmiki kujawskie, podlaskie, mazowieckie i wielkopolskie, Karl Reviczky - sejmiki krakowskie, sandomierskie, lubelskie i podolskie ${ }^{37}$. Zaborcy zakazali sejmikowania na ziemiach zakordonowych ${ }^{38}$. Dla sejmików, które nie obrały posłów w pierwszym terminie, król przymuszony przez Stackelberga wydał powtórne uniwersały na 5 kwietnia. Prawdopodobnym powodem wymuszenia drugiego terminu sejmików było opóźnienie powrotu z Petersburga Adama Ponińskiego, który został przez Rosjan upatrzony na marszałka sejmowego ${ }^{39}$.

z Warszawy przysłany uniwersał na sejmiki, czytając złości biorą. Krwią własną zbroczony, której nikt nie widział (to z pasyi wyjął) i po tym dobry ociec szkalując swój naród, en vérité ça n'a pas du sens commun, tout ce qui font dans cette Varsovie, ils bravent tout le monde", BC 3869, k. 187.

35 Postscriptum do listu A. Młodziejowskiego do I. Krasickiego, 8 III 1773, AGAD, Varia, 15, s. 49-50.

${ }^{36}$ Z. Goliński, Krasicki Ignacy, PSB, t. 15, s. 146; idem, Kalendarz życia i twórczości Ignacego Krasickiego, Poznań 2011, s. 406-418.

37 W. Konopczyński, Pierwszy rozbiór, s. 184; D. Dukwicz, Rosja, s. 154. Zdecydowałem się przedstawiać przebieg sejmików zgodnie z podziałem na przedstawione tu strefy wpływów. Wewnątrz każdej strefy przedstawiam je w kolejności zgodnej z tradycyjną hierarchią sejmików Rzeczypospolitej, której wyrazem jest kolejność zastosowana w spisie posłów (opublikowany on został w: ibidem, s. 300-307; uwagi porządkujące w recenzji z tej pracy autorstwa Urszuli Kosińskiej w: „Biblioteka Epoki Nowożytnej” 2016, 1, s. 214). Zdarzające się niekonsekwencje wynikają z narracji narzuconej przez źródła.

${ }^{38}$ Wiemy, że administracja austriacka nie pozwoliła ani oblatować w grodzie bełskim królewskiego uniwersału zwołującego sejmiki, ani zebrać się na nie mieszkańcom tamtejszego województwa, E. Kuropatnicki do K. Sołtyka, 29 III 1773, LNNBU 571, s. 156.

39 O zaufaniu i nadziejach, jakie Stackelberg pokładał w Ponińskim: D. Dukwicz, Rosja, s. 81, 141. 
Sejmiki w rosyjskiej strefie wpływów

Najwięcej informacji posiadamy o przebiegu sejmików Wielkiego Księstwa Litewskiego ${ }^{40}$. Wiadomości dostarcza korespondencja Stanisława Augusta z podskarbim litewskim Antonim Tyzenhauzem oraz relacje Stackelberga. Źródła pozwalają przedstawić wybór posłów litewskich jako rozgrywkę między królem a posłem rosyjskim. Ten pierwszy musiał działać dyskretnie, opierając się na własnych kontaktach w Wielkim Księstwie i pomocy Tyzenhauza. $\mathrm{W}$ imieniu posła działał przede wszystkim biskup Massalski.

Sejmiki litewskie - podobnie jak zjazdy w innych częściach kraju działały pod presją wojsk zaborczych stacjonujących nieopodal miejsca obrad. Rosyjskie komendy zaopatrzone zostały w instrukcje generała Aleksandra Bibikowa (Aleksandr Bibikov), generała en-chef wojsk rosyjskich. Zgodnie z nią oficerowie mieli informować szlachtę, że bezpieczeństwo kraju zależy od życia w zgodzie z Rosją, rozbiór zaś to konsekwencja porzucenia przyjaźni moskiewskiej i skutek konfederacji barskiej. Szlachtę zapewniano, że wybór posłów na sejm i przyszłe zmiany ustrojowe przyniosą spokój w kraju. Opornym grożono konfiskatą majątku. Dodatkową zachętę miała stanowić obietnica zapłaty wystawionych wcześniej kwitów za dostarczony Rosjanom furaż. Bibikow zaznaczał w swojej instrukcji, że wojsko nie powinno bezpośrednio ingerować w przebieg sejmików, by tworzyć pozór wolności ${ }^{41}$. Stackelberg natomiast, wedle informacji Revickiego, zobowiązywał się do zapewnienia środków do życia dla posłów wybranych z jego nominacji ${ }^{22}$.

Massalski miał przeprowadzić wybór posłów na ośmiu sejmikach: wileńskim, lidzkim, grodzieńskim, starodubowskim, smoleńskim, wołkowyskim, mińskim i rzeczyckim. Nieposiadający własnej klienteli biskup nie wypełnił jednak zadania. Posłowie, których polecił sejmikom, zostali wybrani jedynie na zjazdach odbywających się w Wilnie: wileńskim i starodubowskim (egzulanckim) ${ }^{43}$. Obradujący w tym samym

40 S. Kościałkowski, Antoni Tyzenhauz. Podskarbi nadworny litewski, t. 1, Londyn 1970, passim; J. Michalski, Rejtan i dylematy, s. 183-186; D. Dukwicz, Rosja, s. 154-169.

${ }^{41}$ „Instrukcja oficerom wojska rosyjskiego od generała Bibikow na sejmiki 22 martii 1773 rozesłanych, z Warszawy 26 lutego", BPAU-PANKr 320, k. 343-344v.

${ }^{42}$ „Der russische Minister hat den künftigen Landboten von Lithauen die, so zu sagen, unter Seine Aufsicht stehen werden, bereits versprechen lassen, dass ihnen die Wohnung und der Unterhalt zu Warschau nichts kosten solle", K.E. Reviczky do W.A. Kaunitza, 10 III 1773, Haus- Hof- und Staatsarchiv w Wiedniu (dalej: HHStA), Polen II, 35 (I-III 1773), k. 194.

43 S. Kościałkowski, op. cit., s. 114; D. Dukwicz, Rosja, s. 159. Wybrani z polecenia Massalskiego posłowie zostali zaopatrzeni w instrukcje, które zalecały staranie 
mieście egzulancki sejmik smoleński nie obrał posłów, co należy uznać za porażkę Massalskiego ${ }^{44}$. Tyzenhauz wygrał z biskupem na sejmiku lidzkim, gdzie przeforsował kandydatury chorążego lidzkiego Józefa Narbutta i sędziego grodzkiego lidzkiego Józefa Stypułkowskiego ${ }^{45}$. Massalski nie poradził sobie z sejmikiem grodzieńskim, na którym wspierał go rosyjski generał Abraham Romanius (Avram Romanus). Wybrani tam posłowie, chorąży grodzieński Józef Jelski i sędzia ziemski grodzieński Kazimierz Wolmer weszli na sejmie do stronnictwa królewskiego ${ }^{46}$. Częściowy sukces Massalski odniósł natomiast na sejmiku wołkowyskim, gdzie dokonano wyboru wojskiego wołkowyskiego Antoniego Tołłoczki, który później współdziałał z biskupem przy pracach w delegacji sejmowej. Drugim posłem z tego powiatu został pisarz ziemski wołkowyski Michał Bułharyn, będący stronnikiem podskarbiego litewskiego. Wybór posłów z dwóch stronnictw wskazuje na zawarty na sejmiku kompro$\mathrm{mis}^{47}$. Wpływy królewskie wzięły górę na sejmiku okrojonego powiatu rzeczyckiego, obradującego najprawdopodobniej w Rzeczycy (miasto sejmikowania - Rohaczew, zostało przyłączone do Rosji). Interesy podskarbiego reprezentował tamtejszy starosta Józef Judycki ${ }^{48}$. Dzięki jego zabiegom posłami zostali Jerzy Wirpsza i Michał Pruszanowski, którzy w czasie sejmu współpracowali ze Stanisławem Augustem ${ }^{49}$. W perspektywie późniejszych wydarzeń zupełną klęską rosyjską okazał się wynik sejmiku mińskiego, gdzie obrano rotmistrza mińskiego Stanisława Bohuszewicza i krajczego mińskiego Tadeusza Wołodkowicza, którzy związali się ze stronnictwem monarszym ${ }^{50}$. Zestawienie to pokazuje, że Massalski nie podołał powierzonej mu przez Stackelberga misji.

o powrót zabranych województw do Rzeczypospolitej. Instrukcja wileńska zalecała do łask królewskich Tyzenhauza oraz przedstawiciela opozycji Jana Hylzena; starodubowska zaś - Massalskiego. Może to świadczyć o tym, że na sejmiku odbyła się walka dwóch stronnictw i osiągnięto kompromis, który pozwolił na wybór posłów. Chociaż sejmik starodubowski obrał dwóch posłów: starostę berżnickiego Mateusza Żyniewa i oboźnego Antoniego Kopańskiego, jedynie ten pierwszy dotarł do Warszawy; instrukcja powiatu starodubowskiego, LVIA, SA 4787.

${ }^{44}$ D. Dukwicz, Rosja, s. 161-162.

${ }^{45}$ Ibidem, s. 161.

${ }^{46}$ Ibidem, s. $160-161$.

47 Ibidem, s. 160.

48 E. Rostworowski, Judycki Józef, PSB, t. 11, Wrocław-Warszawa-Kraków 1964, s. 311.

49 Posłowie powiatu rzeczyckiego nie zostali uwzględnieni w drukowanym spisie posłów. Zapewne wieść o ich obraniu i sami posłowie dotarli za późno do Warszawy, aby zostać uwzględnionymi w spisie, który powstał na początku sejmu. Dodatkowo dwór mógł przypuszczać, że sejmik rzeczycki nie dojdzie do skutku, skoro Rohaczew znalazł się za kordonem.

${ }^{50}$ D. Dukwicz, Rosja, s. 162. 
Poseł rosyjski osobiście zaplanował dziesięć pozostałych sejmików litewskich. Rozesłał na prowincję listy, w których wyznaczał osoby odpowiedzialne za ich przebieg oraz w większości wypadków przedstawiał swoich kandydatów do funkcji poselskiej. Posłów nie obrały sejmiki oszmiański, powierzony podskarbiemu wielkiemu litewskiemu Michałowi Brzostowskiemu, upicki, powierzony przedstawicielowi rodziny Karpiów, żmudzki, zalecony tamtejszemu biskupowi Janowi Dominikowi Łopacińskiemu oraz połocki, nad którym czuwał pisarz wielki litewski Mikołaj Tadeusz Łopaciński ${ }^{51}$. Częściowy sukces odnotował Stackelberg na sejmiku wiłkomierskim, gdzie zgodnie z wolą dyplomaty posłem został wojewodzic inflancki Jan Kazimierz Zyberk. Drugim posłem został związany z Tyzenhauzem Michał Tadeusz (?) Morykoni ${ }^{52}$. Sejmik brasławski, powierzony pieczy Józefa Hylzena wojewody mścisławskiego i starosty brasławskiego, obrał związanych $\mathrm{z}$ wojewodą Jerzego Szaumana i Bogusława Dunina Tomaszewicza, tamtejszych sędziów grodzkich ${ }^{53}$. Stackelberg przed sejmikiem zalecał do funkcji poselskiej marszałka brasławskiego Michała Ogińskiego i pisarza skarbowego Ignacego Łopacińskiego; możliwe jednak, że te kandydatury były nie do zaakceptowania dla miejscowej szlachty ${ }^{54}$. Sejmik trocki, powierzony strażnikowi litewskiemu Leonardowi Pociejowi, który w zamyśle Stackelberga miał zostać posłem razem z szambelanem Romerem, nie spełnił oczekiwań dyplomaty. Do Warszawy z tego powiatu przybyli jednomyślnie wybrani sędzia ziemski trocki Jerzy Franciszek Talwosz oraz sędzia grodzki trocki Józef Jeleński, który podczas prac delegacyjnych sympatyzował z kró$l^{1 e{ }^{55}}$. Z punktu widzenia późniejszych wydarzeń klęską okazał się wynik

51 Ibidem, s. 164, 168. „Gazette de France” donosi, że sejmik żmudzki został zerwany, kiedy rosyjski oficer próbował narzucić treść instrukcji poselskiej w języku rosyjskim, P. Ugniewski, op. cit., s. 43.

52 D. Dukwicz, Rosja, s. 164.

53 Przeciwko tej elekcji jeden z przedstawicieli rodziny Mirskich (oboźnic) „z postronnej namowy zaniósł manifest”, J. Hylzen do Stanisława Augusta, 24 III 1773, BC 665, s. 91-92.

${ }^{54}$ D. Dukwicz, Rosja, s. 164-165. „Gazety Wileńskie” 3 kwietnia informowały, że sejmik brasławski w pierwszym terminie rozszedł się, nie obierając posłów, z powodu małej liczby osób przybyłych na sejmik i innych przyczyn manifestowanych przez Mirskiego, oboźnica powiatu brasławskiego. Jednak numer z 17 kwietnia donosił, że na sejmiku przez „dość licznych ichmość pp. urzędników i obywatelów” posłami zostali obrani sędziowie brasławscy Szauman i Tomaszewicz (co prawda gazeta podawała jako datę wyborów posłów 22 marca, jednak jest to oczywista pomyłka, gdyż chodziło o sejmik za powtórnym uniwersałem), „Gazety Wileńskie” 3 i 17 IV 1773, 14 i 16.

55 D. Dukwicz, Rosja, s. 166; A.B. Zakrzewski, Sejmiki Wielkiego Księstwa Litewskiego XVI-XVIII w. Ustrój i funkcjonowanie: sejmik trocki, Warszawa 2000, s. 85. 
sejmiku nowogródzkiego, z którego posłowali uczestnicy sejmowego protestu - podkomorzyc nowogródzki Tadeusz Rejtan oraz pisarzewicz nowogródzki Samuel Korsak. Zgromadzenie to Stackelberg powierzył księciu Józefowi Radziwiłłowi ${ }^{56}$. Jerzy Michalski sugerował, że wynik sejmiku nowogródzkiego mógł być efektem wpływów księcia kanclerza Michała Czartoryskiego i współpracującego z nim kasztelana nowogródzkiego Józefa Niesiołowskiego ${ }^{57}$. W sferze domysłów pozostaje więc, czy posiadający rozległe wpływy na Litwie Czartoryski zaangażował się w sejmiki, skoro informował zagranicznych posłów, że nie przyłoży do nich ręki i - pokładając zbytnią nadzieję w swoich wpływach - zapewniał, że z tego powodu nie dojdą one do skutku ${ }^{58}$. Korzystniejszy dla Stackelberga wynik przyniósł sejmik brzesko-litewski, którym zgodnie z wolą posła rosyjskiego opiekował się kasztelan brzeski Marcin Matuszewicz. Obrano tam miecznika litewskiego Michała Hieronima Radziwiłła, który został później litewskim marszałkiem konfederacji sejmowej, oraz Franciszka Ursyna Niemcewicza ${ }^{59}$. W Pińsku zgodnie z wolą posła rosyjskiego oddelegowano do stolicy sędziego ziemskiego Adama Skirmunta. Jednak wbrew ambasadorskim zaleceniom mandatu nie otrzymał sędzia grodzki Michał Szyrma, którego miejsce zajął sędzia grodzki piński Ignacy Kurzeniecki ${ }^{60}$.

Połowiczny sukces Stackelberga na litewskich sejmikach należy tłumaczyć brakiem rozeznania w sprawach prowincjonalnych. Prawdopodobnie $z$ tego powodu ambasador nie zaplanował przebiegu sejmików kowieńskiego i mozyrskiego. Na pierwszym z nich nie widać wpływów rodziny Zabiełłów, która najpewniej w ogóle nie uczestniczyła w obradach. Co więcej, zdaniem podskarbiego litewskiego, Stanisław August nie ufał im na tyle, aby prosić o zaangażowanie w sprawę wymagającą wielkiej dyskrecji. Z pełnomocnictwa Tyzenhauza kandydatów wystawił tu kasztelan witebski Szymon Siruć. W efekcie posłami obrano łowczego i sędziego grodzkiego kowieńskiego Jerzego Rodziewicza (współpracującego z reguły z Zabiełłami) oraz strażnika

${ }^{56}$ Posłowie tego województwa zostali zaopatrzeni w instrukcję, która najgoręcej protestowała przeciwko rozbiorowi. Może to świadczyć o tym, że wpływy rosyjskie/ radziwiłłowskie nie odegrały żadnej roli na tym sejmiku.

57 J. Michalski, Reytan (Rejtan, Reyten) Tadeusz, PSB, t. 31, Wrocław-Warszawa-Kraków 1988-1989, s. 231-232.

58 „Le vieux prince chancellier n'est par content du tout. Il avoit généralement assuré, que nous ne ferions par tenir une seule diettine puis qu'il ne s'en metoit pas", G. Benoît do Fryderyka II, 24 III 1773, GStA PK, 1 HA Rep. 96, nr 52e.

59 D. Dukwicz, Rosja, s. 167.

${ }^{60}$ Ibidem, s. 167-168. 
kowieńskiego Tomasza Michniewicza ${ }^{61}$.W sejmik mozyrski osobiście zaangażował się Stanisław August, dzięki któremu wybrani zostali podkomorzy mozyrski Konstanty Jeleński i pisarz ziemski mozyrski Adam Ipohorski-Lenkiewicz ${ }^{62}$.

W obszarze kontrolowanym przez Rosję znalazł się prawdopodobnie także sejmik kijowski. Pomimo braku informacji źródłowych, położenie geograficzne oraz wiadomości o interwencji wojsk rosyjskich każą przyjąć, że należał on do strefy Stackelberga. Pierwszy zjazd, zagajony przez podkomorzego kijowskiego Michała Steckiego, rozszedł się, nie obierając nawet marszałka sejmikowego, a szlachta zaniosła do grodu manifest, który rozkolportowała potem na cały $\mathrm{kraj}^{63}$. Zgodnie z informacjami prasy zagranicznej, na sejmik zwołany powtórnym uniwersałem przybyli kasztelan kijowski Józef Stempkowski i podczaszy koronny Szczęsny Czacki w towarzystwie wojsk rosyjskich ${ }^{64}$. Wspólna misja regalisty Stempkowskiego i Czackiego wydaje się jednak mało prawdopodobna, gdyż pod względem politycznym nic ich nie łączyło, dodatkowo podczaszy cały czas znajdował się pod nadzorem wojsk rosyjskich ${ }^{65}$. Powtórny sejmik kijowski również nie wybrał posłów.

W źródłach nie znajdujemy wzmianek na temat sejmików słonimskiego i orszańskiego, które nie wybrały posłów na sejm ${ }^{66}$.

${ }^{61}$ M. Jusupović, Prowincjonalna elita litewska w XVIII wieku. Działalność polityczna rodziny Zabiełtów w latach 1733-1795, Warszawa 2014, s. 148, 277-278. Przed sejmem 1776 r. Antoni Tyzenhauz pisał do króla, że „na sejm przeszły [tj. 1773 r.] posłów Siruć wystawiał na moją spod ręki inspiracyją", 18 II 1776, BC 716, s. 355.

${ }^{62}$ S. Kościałkowski, op. cit., s. 97; D. Dukwicz, Rosja, s. 168.

63 Wypis z ksiąg grodzkich żytomirskich, AGAD, Archiwum Prozorów i Jelskich 138, s. 677-678.

${ }^{64}$ P. Ugniewski, op. cit., s. 43.

65 „Diariusz niewoli” Szczęsnego Czackiego notuje, że w dniach 2-8 kwietnia „nic nie było". Przypuszczam więc, że Czacki nie pojawił się na sejmiku, a jego ówczesna działalność przedsejmowa ograniczyła się zapewne do wyjazdu 18 kwietnia „do Koczerowa, do Najświętszej Panny cudami słynącej dla uproszenia o wstawienie się do Boga, aby dał dobre rady i ducha cnotliwego zasiadającym posłom na sejm w Warszawie", BC 1173, s. 496. Jak twierdzi Konopczyński, Czacki nie zdecydował się nawet rozesłać pisemka swojego autorstwa „Odpowiedzi na powierzchowne przyczyny przywłaszczenia krajów polskich”, W. Konopczyński, Czacki Feliks (Szczęsny), PSB, t. 4, Warszawa-Kraków-Łódź 1938, s. 141. O rojalistycznej działalności Stempkowskiego: T. Srogosz, Początki budowy stronnictwa królewskiego na Ukrainie przez Józefa Gabriela Stempkowskiego (koniec lat sześćdziesiatych - początek siedemdziesiątych XVIII w.), „Przegląd Nauk Historycznych” 5, 2006, 1, s. 171-183.

${ }^{66}$ D. Dukwicz, Rosja, s. 158. 
Sejmiki w austriackiej strefie wpływów

W odróżnieniu od działalności posła rosyjskiego, postępowanie dyplomatów austriackiego i pruskiego było zupełnie niezorganizowane. Reviczky w raportach do kanclerza Wenzela Antona Kaunitza przyznawał, że praca nad sejmikami nie postępowała w zadowalający sposób. Skarżył się, że przygotowania opóźniał Stackelberg, który wyczekiwał na szczegółową instrukcję (tzw. Plan Panina) i nie pozwalał na żadne działania, które mogłyby się okazać niezgodne z decyzjami Petersburga. W tej sytuacji Reviczky ograniczył się do rozsiewania gróźb wśród szlachty. W trzy dni po pierwszym terminie sejmików zauważał, że terror odniósł zamierzone skutki w Warszawie (a stanowiła ona teren, za który odpowiadał jego pruski kolega). Wyrażał natomiast niepewność, czy tak samo efektywnie groźby podziałały na prowincji ${ }^{67}$. Zmartwieniem austriackiego posła były fundusze, których dyplomatom cały czas brakowało. Kiedy doszły do niego niepomyślne informacje o wynikach pierwszej tury sejmików, stwierdził post factum, że o ile podczas sejmu najwięcej pieniędzy będzie trzeba przekazać marszałkowi, to przed sejmikami 22 marca należało dobrze zabezpieczyć finansowo osoby, które zostaną wysłane na prowincję i odpowiednio pokierują zgromadzeniami ${ }^{68}$.

W relacjach Revickiego pojawiają się trzy postaci utrzymujące stałe kontakty z ambasadą wiedeńską: Teodor Wessel, referendarz litewski Andrzej Ogiński i krajczy koronny Józef Potocki. Współpracujący ze Stackelbergiem Wessel został oddelegowany do wsparcia działań w Małopolsce. Wyruszył do województw krakowskiego i sandomierskiego z zaleceniem dyplomaty austriackiego, aby nakłonić szlachtę do akceptacji rozbioru oraz uświadomić jej, że spokój w zajętej prowincji leży we wspólnym interesie tamtejszych obywateli i dworu austriackiego. 0 misji podskarbiego Reviczky uprzedził generałów austriackich ${ }^{69}$. Z kolei Ogiński pełnił funkcję łącznika między królem a ambasadą wiedeńską. Referendarz znał Revickiego prawdopodobnie z Wiednia, gdzie był w latach

67 „Furcht und Drohungen [--] zu Warschau und in dem benachbarten Bezirk eine erspriesliche Wirkung hervorgebracht, in denen entfernteren Provinzen aber ihre Kraft verliehren", K.E. Reviczky do W.A. Kaunitza, 26 III 1773, HHStA, Polen II, 35 (I-III 1773), k. 230v. Austriacy wydali deklarację na kontrolowane przez siebie sejmiki, która prawdopodobnie zawierała groźby mające na celu realizację planów mocarstw ościennych, J. Michalski, Rejtan i dylematy, s. 183.

68 K.E. Reviczky do W.A. Kaunitza, 26 III 1773, HHStA, Polen II, 35 (I-III 1773), k. $229 \mathrm{v}-230$.

${ }^{69}$ K.E. Reviczky do W.A. Kaunitza, 16 III 1773, ibidem, k. 36v-37; W. Konopczyński, Geneza, s. 194. 
1771-1772 posłem Rzeczypospolitej, zatem ich znajomość mogła służyć jako pretekst skrywający prawdziwe przyczyny narad w domu austriackiego dyplomaty ${ }^{70}$. Niedysponujący ani szczegółowym planem działania, ani partią austriacką w Rzeczypospolitej, Reviczky starał się przez Ogińskiego, niejako wbrew polityce rosyjskiej, nakłonić króla i Czartoryskich do zaangażowania się w sejmiki. Zakładał bowiem (obawiając się, czy zbierze się dostateczna liczba posłów), że najważniejszą kwestią jest rozpoczęcie sejmu ${ }^{71}$. Trzeci z polityków wymienionych przez Revickiego, krajczy Potocki wyjechał z Warszawy zaopatrzony w listy polecające do generała Pergena. Miał zająć się organizacją sejmików „na południu”72. Ambasador austriacki wierzył w więzy klientarne, które łączyły lokalną szlachtę z Potockimi i miał nadzieję, że ułatwią one obrót spraw. Reviczky sugerował wynagrodzenie krajczego za jego działania na sejmikach, a następnie reprezentowanie interesów austriackich na sejmie, nadaniem mu starostw ${ }^{73}$. Misja Potockiego nie może jednak zostać uznana za

70 Z. Zielińska, Ogiński Andrzej, PSB, t. 23, Wrocław-Warszawa-Kraków 1978, s. 597.

71 „Da ich hier noch gar keine Anstalten zu der gleichwohl nahen Versammlung der Dietinen und Wahl der Landboten sehe, so habe ich den Herrn Grafen Oginski befragt, was er davon hielte, und ob er glaubte, dass es zur wirklichen Wahl der Landboten kommen würde oder nicht. Er zweifelt zwar nich, dass in Grosspolen, wo die Preussen, und in Litauen, wo die Russen stünden, diese Wahlen vor sich gehen würden; aus dem südlichen Teile von Polen hingegen dörften die Landboten etwa ausbleiben, weilen daselbst niemand die Wahlen betreiben, und weder der König, noch die Czartoriskische Familie sich darum annehmen wollte, aus Beisorge, ihre Bemühungen mögten Verdacht einer Cabale [tj. współpracę Familii z zaborcami] erwecken. Meines Orts habe ich dem Grafen Oginski nicht verhalten, was für schlimme Folgen ein fruchtloser oder aus Mangel der Landboten etwa gar nicht zu Stand kommender Reichstag gewis nach sich ziehen würde, und ihn ersucht, solche dem Könige und denen Czartoriski bei Zeiten vorzustellen, damit sie durch ihre Unthätigkeit das ganze Land und die Privat Personnen nicht derer gerechten Ahndung der drei Höfe aussetzen. Herr Graf Oginski hat mir versprochen hiervon Gebrauch zu machen und mich eurer gebetten, ich mögte auch meinerseits ihnen die damit verknüpfte Gefahren beibringen", K.E. Reviczky do W.A. Kaunitza, 6 III 1773, HHStA, Polen II, 35 (I-III 1773), k. 183v-185.

72 K.E. Reviczky do W.A. Kaunitza, 13 III 1773, ibidem, k. 199v.

73 „Her Graf von Pergen schreibet mir, er habe die erwähnte Starosteien dem Herrn Grafen Potocki nur mit der Bedingniss ertheilet, dass er seinen gantzen Kredit und die durch seine Reichthumer erworbene Macht geltend machen und sowohl sich mit seinen Freunden und Anhängern zu Landboten bei denen Dietinen erwählen zu lassen, als sodann bei dem Reichstag selbst das allerhöchste kaiser.-königl. Interesse werkhthätig zu unterstützen. Es dörfte vielleicht nicht untuhnlich sein, ihm zu verstehen zu geben, dass ihm diese Starosteien von neuem entgehen könnten, wofern er diese Bedingung nicht genau erfüllen sollte, besonders da es bei denen Pohlen nichts seltens ist, nach erreichtem Endzweck ihre Verbindungen zu vergessen", K.E. Reviczky do W.A. Kaunitza, 20 III 1773, ibidem, k. 224r-v. 
udaną. Sam kandydował w Lublinie, gdzie sejmik został zerwany poprzez wpływy wojewodziny bracławskiej Anny Jabłonowskiej ${ }^{74}$. Jest to jeden z licznych przykładów pokazujących wpływ niektórych kobiet na politykę w epoce stanisławowskiej. Mimo braku prawnej możliwości uczestniczenia w pracach sejmikowych, Jabłonowska wykorzystała zapewne związki klientarne swojej rodziny w celu niedopuszczenia do obrania lubelskich posłów ${ }^{75}$.

Na sejmiku krakowskim zebrało się podobno ponad 200 osób. Wybory odbyły się w obecności dwóch oficerów austriackich, przybyłych z tłumaczem, którzy mieli poinformować szlachtę o stacjonujących za miastem 30 huzarach $^{76}$. Młodziejowski zawczasu sugerował, żeby o mandat starał się tu podczaszy krakowski Aleksander Łętowski, dobierając sobie kolegó $\mathrm{w}^{77}$. O pracę na rzecz sejmiku prosił kasztelana wojnickiego Stanisława Kostkę Dembińskiego, który (jak świadczy inny list kanclerza) nosił się raczej z zamiarem zrywania sejmików w Wielkopolsce ${ }^{78}$. Zabiegi pieczętarza musiały odnieść skutek, skoro posłem z krakowskiego zostali m.in. starosta pieczonowski Franciszek Dembiński ${ }^{79}$ oraz podkomorzy krakowski Stanisław Łętowski (z tego poselstwa Młodziejowski wyrażał duże zadowolenie) ${ }^{80}$. Oceniając instrukcję poselską i późniejsze działania posłów, wśród których znalazł się pułkownik Feliks Oraczewski - należałoby uznać, że sejmik obradujący pod wiedeńską kuratelą wybrał regalistycznych posłów ${ }^{81}$. Może to być także uzasadnieniem stawianego wyżej

${ }^{74}$ W. Szczygielski, Potocki Józef, PSB, t. 28, Wrocław-Warszawa-Kraków 1984-1985, s. 74. Jabłonowska chwaliła się zerwaniem tego sejmiku swojej siostrze Teofilii Sapieżynie w liście z 27 marca 1773 r. Księżna relacjonowała, że w czasie jej destrukcyjnej działalności na sejmiku Potocki „przyrzekł dla mnie od Austryi zemstę, złości swej żadnej nie znajdując tamy. [--] Głośne przegróżki komendant lubelski na mnie czynił od krajczego, dowiedziawszy się o moim w to wchodzeniu, tak dalece, że kapitan moskiewski tu u mnie stojący i mój przyjaciel, lecz nic nie wiedzący, przestrzegał mnie o tym", „Dziennik Teofilii Sapieżyny”, Biblioteka Polska w Paryżu 46, s. 461-462.

75 O politycznym zaangażowaniu magnatek w okresie konfederacji barskiej, por. W. Konopczyński, Kiedy nami rzadziły kobiety, Londyn 1960. Najnowsza literatura dotycząca uczestnictwa kobiet w polityce XVIII w. w: Stynne kobiety w Rzeczypospolitej XVIII wieku, red. A. Roćko, M. Górska, Warszawa 2017.

76 J. Michalski, Rejtan i dylematy, s. 183-184.

77 A. Młodziejowski do A. Łętowskiego, 10 III 1773, AGAD, Varia, 15, s. 55-57.

78 A. Młodziejowski do S.K. Dembińskiego, 11 III 1773, AGAD, Varia, 15, s. 57.

${ }^{79}$ Na sejmie należał on do prokrólewskiej mniejszości sejmowej, W. Konopczyński, Dembiński Stanisław Kostka, PSB, t. 5, Warszawa-Kraków-Łódź 1939-1946, s. 75.

80 A. Młodziejowski do S.K. Dembińskiego, 31 III 1773, AGAD, Varia, 15, s. 75.

${ }^{81} \mathrm{~W}$ historiografii mamy do czynienia z pewną nieścisłością co do wybranego na tym sejmiku podkomorzyca sieradzkiego Walewskiego. Ryszard Chojecki identyfikuje tu Romualda (R. Chojecki, Patriotyczna opozycja na sejmie 1773 r., KH 79, 1972, 3, s. 561), 
przypuszczenia, że Austriacy kładli nacisk głównie na dojście sejmików, nie wywierając wpływu na ich postanowienia.

Do przeprowadzenia sejmiku sandomierskiego Młodziejowski zachęcał regalistę, podkomorzego sandomierskiego Antoniego Potkańskiego ${ }^{82}$. Biskup krakowski Kajetan Sołtyk wysłał tam z kolei starostę dźwinogrodzkiego Feliksa Sołtyka z zaleceniem, aby nie dopuścił do obrania posłów ${ }^{83}$. W pierwszym terminie sejmik rozszedł się, ogłaszając manifest, że rada senatu, która zwołała sejm, obradowała nielegalnie ${ }^{84}$. Zgodnie z informacjami „Gazette de France” sejmik mieli zerwać sami Austriacy, którzy nie chcieli dopuścić do wyboru starosty sądeckiego Stanisława Małachowskiego ${ }^{85}$. Sejmik zwołany w drugim terminie wybrał siedmiu posłów z Marcinem Lubomirskim na czele ${ }^{86}$. Zagraniczne gazety podawały zatem fałszywą informację, donosząc, że i ten sejmik został zerwany przez niejakiego Tylatyckiego, który miał oprotestować wybór posłów w towarzystwie wojsk zagranicznych. W „Gazette de France” znajdujemy także intrygującą wiadomość, że o ile pierwszy sejmik kontrolowały wojska austriackie, o tyle sejmik zwołany za powtórnym uniwersałem odbywał się w asyście wojsk pruskich ${ }^{87}$.

O sejmiku łuckim posiadamy jedynie informacje z drugiej ręki. Król pisał do Tyzenhauza, że swoich wpływów będzie tam używał krajczy Potocki ${ }^{88}$. Chociaż zgodnie z pierwotnymi ustaleniami Wołyń miał być

Dorota Dukwicz zaś byłego barzanina Michała (eadem, Rosja, s. 301). Michał Kobierecki nie odnotował ich posłowania na sejm 1773 r.: Romuald 27 kwietnia 1773 r. otrzymał szarżę generała adiutanta (posłował na sejm 1778 r.), Michał zaś „po powrocie do Rzeczypospolitej [po porażce Baru - przyp. P.S.] zaniechał wystąpień przeciwko królowi, zmieniając swoje stanowisko. Po pierwszym rozbiorze zbliżył się do stronnictwa regalistycznego. Dzięki temu został posłem na sejm w 1776 r. z województwa krakowskiego", M. Kobierecki, Walewscy herbu Kolumna w XVII-XVIII wieku. Genealogia. Majętności. Działalność publiczna, Łódź 2008, s. 186, 203, 204. Konopczyński, opisując losy byłych konfederatów, również odnotowuje posłowanie Michała Walewskiego jedynie na sejm 1776 r., W. Konopczyński, Konfederacja barska, t. 2, s. 732.

${ }^{82}$ A. Młodziejowski do A. Potkańskiego, 10 III 1773, AGAD, Varia, 15, s. 54. W. Szczygielski, Potkański Antoni, PSB, t. 27, Wrocław-Warszaw-Kraków 1973, s. 721.

83 Patrz przyp. 141.

${ }^{84}$ G. Benoît do Fryderyka II, 27 III 1773, GStA PK, 1 HA Rep. 96, nr 52e.

${ }^{85}$ P. Ugniewski, op. cit., s. 38-39.

${ }^{86}$ Do powrotu do kraju w grudniu 1772 r. nakłaniał go Stanisław Konarski. W. Szczygielski, Lubomirski Marcin, PSB, t. 18, Wrocław-Warszawa-Kraków 1973, s. 36; S. Konarski do M. Lubomirskiego, 29 XII 1772, w: W. Konopczyński, Stanisław Konarski, Warszawa 1926, s. 421-422. Marcin Lubomirski miał uczestniczyć także w niedoszłym marcowym sejmiku, J.N. Chęcki do A. Chmary, 29 III 1773, BJ 6666, k. 190.

87 P. Ugniewski, op. cit., s. 38-39, 43-44.

${ }^{88}$ Stanisław August do A. Tyzenhauza, 15 III 1773, BC 715, s. 211; D. Dukwicz, Rosja, s. 169. 
nadzorowany przez Stackelberga, to wpływy ciążącej ku Austrii rodziny Potockich mogły spowodować, że w praktyce zaczął planować go Reviczky. Nawet jeśli Józef Potocki starał się przeforsować swoich kandydatów, to marcowy sejmik wołyński rozszedł się, nie obierając posłów. Szlachta wydała przy tym głośny manifest rozkolportowany w wielu odpisach. Doniesienia z Warszawy podawały, że Austria pozwoliła wyjechać na ten sejmik zza kordonu staroście bełskiemu Stanisławowi Szczęsnemu Potockiemu. Donoszono też, że został on obrany posłem ${ }^{89}$, co nie było prawdą. Sejmik w drugim terminie również nie wybrał posłów.

Sejmik podolski także rozszedł się, nie obierając posłów. Z korespondencji królewskiej wynika, że miał tam działać wysłany przez Adama Kazimierza Czartoryskiego niejaki Borysławski ${ }^{90}$. Sam książę Adam, starosta generalny ziem podolskich, zgodnie z rosyjskim dictum nie brał aktywnego udziału w sejmikach, lecz szykował się do podróży do Petersburga, żeby złożyć hołd poddańczy Katarzynie II ${ }^{91}$. Królewska wzmianka o wysłaniu Borysławskiego przez księcia Adama oraz informacja Revickiego, że poprzez Ogińskiego namawia Czartoryskich do zaangażowania się w sejmiki, pozwala jeszcze raz zadać pytanie, czy pokutująca w literaturze teza o bierności Czartoryskich jest zgodna $\mathrm{z}$ realiami. W okresie sejmikowym - o czym wspomniano wyżej - na Podolu przebywał za to biskup Krasiński ${ }^{92}$. Władysław Konopczyński utrwalił opinię o zrywaniu

${ }^{89}$ J.N. Chęcki do A. Chmary, 29 III 1773, BJ 6666, k. 190. Podobne wieści dotarły do Teofili Sapieżyny, „Dziennik Teofilii Sapieżyny”, Biblioteka Polska w Paryżu 46, s. 466.

90 D. Dukwicz, Rosja, s. 173. Informacja ta pochodzi z listu Stanisława Augusta do Tyzenhauza z 18 III 1773 (BC 715, s. 213). Być może mowa tu o Antonim Marcinie Borysławskim, niegdyś ważnym współpracowniku Familii, następnie konfederacie barskim, albo o jego synu Andrzeju, W. Konopczyński, Borzysławski vel Borysławski Antoni Marcin, PSB, t. 2, Kraków 1936, s. 371; K. Kuras, Wspótpracownicy i klienci Augusta A. Czartoryskiego w czasach saskich, Kraków 2010, s. 137-138, 182-184, 258, 263.

91 Wyruszył on do Petersburga 9 kwietnia 1773 r., J. Michalski, Rejtan i dylematy, s. 166.

${ }^{92}$ Krasiński, podobnie jak część byłych barzan, nie chciał przykładać ręki do rozbioru, ale (po odpowiednich ustępstwach zaborców) był gotów pracować na sejmie nad wprowadzeniem zmian ustrojowych w duchu republikańskim. W liście do Sołtyka donosił o swoim wyjeździe i braku możliwości działania: „wyjeżdżam na Podole z tą zawsze intencyją, żebym mógł powrócić, służyć ojczyźnie i Kościołowi, ale przyznam się WXMci, że jak prędko żadna insza potencyja prócz tych trzech nie będzie gadała ze mną za ojczyzną, tak wszystkie moje usiłowania, perory w senacie i lamentacyje obrócą się w pośmiewisko [--]. Ja powrócę, jak tylko będzie można najprędzej, ale moje zdanie powiadam WXMci, że wolę nic nie robić, niżeli się mazać zgubą wolnych, albo nad nią kondukt śpiewać pontificaliter. [--] Przyszlę z Podola moje refleksyje super forma regiminis, a teraz jestem prawdziwy przyjaciel i sługa", A. Krasiński do K. Sołtyka, 23 II 1773, LNNBU 331, k. 31. 
przez niego zjazdów ${ }^{93}$, co zostało podważone przez Jerzego Michalskiego, który uznał, że przy braku dowodów na działalność biskupa należy stwierdzić, iż rwanie sejmików nie zgadzało się z ówczesnymi poglądami Krasińskiego ${ }^{94}$.

Zebrany w kościele oo. Jezuitów w Winnicy sejmik województwa bracławskiego z powodu małej liczby obecnych 22 marca wstrzymał się $\mathrm{z}$ procedowaniem do dnia następnego. Nazajutrz, pomimo liczniejszego zgromadzenia i ułożenia wstępnych punktów do instrukcji, sejmik pod przewodnictwem skarbnika bracławskiego Piotra Barczewskiego rozszedł się, nie obierając posłów z powodu braku chętnych. Z korespondencji Młodziejowskiego wiemy jednak, że w tym samym czasie „na wsi prywatnie jakoweś niby laudum i elekcyja tak marszałka i asesorów, jako też posłów na sejm nastąpić miały" 95 . W rzeczywistości doszło do rozdwojenia obrad. Zgromadzeni poza kościołem obrali na posłów szambelana królewskiego Maksymiliana Woronieckiego, książąt Antoniego i Michała Czetwertyńskich, horodniczego zwinogrodzkiego Pawła Sudymontowicza Czeczela, podstolego brzeskiego Józefa Kownackiego i cześnika żydaczowskiego Michała Wielowieyskiego. Ich instrukcja nie została jednak oblatowana w grodzie winnickim. Antoni Czetwertyński, spiritus movens nielegalnego sejmiku, bałamutnie tłumaczył to uchybienie sprzeciwem „obłąkanego susceptanta”, który miał się obawiać wpisania do ksiąg punktu potępiającego królobójców ${ }^{96}$.

Nie znamy przebiegu egzulanckiego sejmiku województwa czernihowskiego obradującego we Włodzimierzu, który nie obrał posłów. Znany jest jedynie manifest, w którym szlachta wyraziła sprzeciw wobec obrad zagrożonych obcą przemocą ${ }^{97}$.

\section{Sejmiki w pruskiej strefie wpływów}

Z relacji Benoît wynika, że zachęcał on szlachtę do udziału w sejmie poprzez obietnicę ustanowienia republikańskiego ustroju. Jednocześnie bez ogródek informował, że wybrani posłowie będą musieli podpisać

93 W. Konopczyński, Konfederacja barska, t. 2, s. 706-707.

94 J. Michalski, Rejtan i dylematy, s. 178-179.

95 Wypis z ksiąg grodzkich winnickich pod datą 6 kwietnia 1773 r. oraz korespondencja dotycząca okoliczności tego sejmiku, BC 799, k. 1009-1011.

96 A. Czetwertyński do A. Młodziejowskiego, 28 III 1773, BC 799, k. 1004-1005. Stanisław August stwierdzał wprost nielegalność poselstwa Czetwertyńskiego et consortes, Mémoires, s. 573.

97 Manifest obecny w BPAU-PANKr 320, k. 251, oraz LNNBU 573, s. 273-275. 
zgodę na rozbiór oraz porzucić wszelką nadzieję na detronizację Stanisława Augusta ${ }^{98}$. Najprawdopodobniej sprawny wybór posłów na terenach powierzonych kontroli dyplomaty pruskiego spowodowany był przede wszystkim nadziejami na złagodzenie rygorów w gospodarce i strachem przed wojskiem pruskim. Benoît chwalił się Fryderykowi II, że udało się przeprowadzić sejmiki bez marnowania pieniędzy ${ }^{99}$.

Sejmiki Wielkopolski właściwej obradowały w 1773 r. zgodnie ze zmianami administracyjnymi wprowadzonymi na sejmie repninowskim, który utworzył województwo gnieźnieńskie z powiatów gnieźnieńskiego i kcyńskiego. Po obraniu posłów na zgromadzeniach powiatowych, w Poznaniu zebrał się przedsejmowy sejmik generalny ${ }^{100}$. W sejmiki wielkopolskie zaangażował się, posiadający w regionie dość rozległe wpływy, kanclerz Młodziejowski. Z prośbą o wybór odpowiedzialnych posłów, jednak nie proponując konkretnych nazwisk, zwrócił się do współpracujących z ambasadą rosyjską kasztelana poznańskiego Józefa Mielżyńskiego i pisarza wielkiego koronnego Kazimierza Raczyńskiego (wprost prosił tego rosyjskiego jurgieltnika o uczestnictwo w sejmie) ${ }^{101}$. Do nich odsyłał osoby zgłaszające swoje kandydatury, np. Adama Zakrzewskiego, miecznika kaliskiego ${ }^{102}$. Frakcję opozycyjną wobec współpracowników Młodziejowskiego tworzyli Sułkowscy. Po sejmikach książę Antoni miał pretensje do brata Augusta o niedostateczne zaangażowanie się w pracę nad zgromadzeniami i pozostawienie ich w rękach przyjaciół kanclerza $^{103}$. Konopczyński na podstawie punktów do instrukcji poselskich uznał, że wpływy Raczyńskiego wzięły górę na sejmikach poznańskim, kaliskim i gnieźnieńskim, bo pominęły one w instrukcji punkt o ustanowieniu Rady Nieustającej ${ }^{104}$. Jej ustanowienie zostało jednak wpisane do

98 „Tous ces nonces ont eté prévenus expressément et clairement, qu'il falloit avant toute chose se préparer à signer à la diètte prochaine le traité de cession, et bannir en second lieu toute idée de déthrônement; qu'en revanche nous contribuirions de tout notre pouvoir à bannir l'anarchie et à faire établir un gouvernement véritablement républicain, qui soit stable et solide, de sorte qu'ils ne pourront pas s'excuser le moins du monde de ne pas avoir scu ce qu'il y auroit à régler à la diètte", G. Benoît do Fryderyka II, 27 III 1773, GStA PK, 1 HA Rep. 96, nr 52e.

${ }^{99}$ G. Benoît do Fryderyka II, 10 IV 1773, ibidem.

100 VL 7, s. 349-350; W. Kriegseisen, Sejmiki Rzeczypospolitej szlacheckiej w XVII i XVIII wieku, Warszawa 1991, s. 261; W. Filipczak, Życie sejmikowe prowincji wielkopolskiej w latach 1780-1786, Łódź 2012, s. 188.

101 A. Młodziejowski do J. Mielżyńskiego, 8 III 1773, AGAD, Varia, 15; A. Młodziejowski do K. Raczyńskiego, 8 III 1773, ibidem.

${ }_{102}$ A. Młodziejowski do A. Zakrzewskiego, 9 III 1773, ibidem.

103 W. Konopczyński, Geneza, s. 198.

104 Ibidem, s. 194. 
instrukcji generalnej, na czym zależało tak Sułkowskim, jak i Stackelbergowi ${ }^{105}$. Ponadto nieformalny przedstawiciel Francji w Rzeczypospolitej, Wojciech Jakubowski, zakwalifikował posłów kaliskich i poznańskich jako oddanych Rosji ${ }^{106}$.

Przebieg sejmików województwa sieradzkiego poznajemy z korespondencji generała Józefa Zaremby. Był on namawiany do kandydowania z ziemi wieluńskiej przez podkomorzego wieluńskiego Adama Myszkowskiego ${ }^{107}$. Natomiast biskup kujawski Antoni Ostrowski przekonywał go, aby starał się o mandat z sieradzkiego. Ostatecznie generał dał się obrać z Sieradza, informując o tym listownie szlachtę wieluńską. Kandydaci, którzy deklarowali chęć posłowania z Wielunia (Franciszek Stadnicki, starosta ostrzeszowski, Aleksander Mączyński, chorąży sieradzki, Władysław Biernacki, chorąży sieradzki i Eustachy Skórzewski, cześnik bracławski), zrezygnowali z ubiegania się o mandat. Ich wcześniejsze decyzje były podyktowane jedynie chęcią pokrzyżowania planów byłemu barzaninowi. Swoją kandydaturę zgłosił tylko cześnik wieluński Feliks Niemojewski, upraszając sobie jako współkandydata marszałka zjazdu, podczaszego ostrzeszowskiego Ksawerego Walewskiego. Sejmik wieluński przebiegał wśród sporów dotyczących rozwiązania kwestii majątkowych po zmarłym bracie Skórzewskiego. Po zakończeniu obrad powierzono Niemojewskiemu zredagowanie instrukcji według podanych punktów. Kiedy przyjechał do Dąbrowy, aby odczytać ostateczną wersję dokumentu, okazało się, że znacznie odbiega ona od zaleceń sejmiku. Oburzony Walewski wyciął z instrukcji swój podpis, złożony prawdopodobnie in blanco. Nie przeszkodziło to Niemojewskiemu oblatować dokumentu w grodzie i wyruszyć z nim do Warszawy. Walewski wraz z dużą grupą szlachty miał zareagować manifestem kwestionującym legalność instrukcji Niemojewskiego ${ }^{108}$. Warto zwrócić uwagę, że Dąbrowa należała do konającego brata biskupa krakowskiego, Tomasza Sołtyka. Fakt, że właśnie tam zebrano się, aby odczytać instrukcję, może być podstawą do przypuszczeń, iż jeden z posłów ziemi wieluńskiej należał do klienteli Sołtyków ${ }^{109}$.

105 Kopia instrukcji wielkopolskiej (wypis z ksiąg poznańskich), AGAD, Zbiór Popielów 123, k. 46v.

106 P. Ugniewski, op. cit., s. 37.

107 A. Myszkowski do J. Zaremby, 6 II 1173, BK 2120. Jako kolegę z ziemi wieluńskiej zalecał mu niejakiego Wielowieyskiego.

108 W. Orłowski do J. Zaremby, 2 IV 1773, BK 2120. Zarówno Walewski, jak i Niemojewski figurują w spisie posłów jako reprezentanci ziemi wieluńskiej.

109 E. Burda-Ricklefs, Sołtyk Tomasz, PSB, t. 40, s. 435-436. Dwie różne instrukcje oraz punkty do instrukcji ułożone na sejmiku znajdują się w Tekach Pstrokońskiego, 
Zaremba, obrany posłem z sieradzkiego, za kolegę z powiatu radomskiego otrzymał rekomendowanego przez Ostrowskiego stolnika piotrkowskiego Jana Tymowskiego. Biskup ręczył, że jest to człowiek „daleki od zdrady ojczyny, owszem jej dobrze życzy i w komisarstwie daje dowody"110. Po wyborach sejmikujący rozjechali się, powierzając przygotowanie instrukcji i zebranie potrzebnych podpisów marszałkowi sejmikowemu, a zarazem posłowi szadkowskiemu Michałowi Radoszewskiemu. Dokument w trakcie peregrynacji po dobrach uczestników sejmiku został pokreślony i zaopatrzony w odrzucone na sejmiku punkty. Na dziewięć dni przed rozpoczęciem sejmu Radoszewski wysłał do Zaremby laudum i instrukcję, która $z$ braku podpisów asesorskich nie mogła być oblatowana w grodzie, a zatem nie miała mocy prawnej. Obowiązek zdobycia niezbędnych podpisów zrzucono na barki generała ${ }^{111}$.

Wybór posłów z województwa łęczyckiego należy uznać za porażkę mocarstw rozbiorowych. Wybrani tam posłowie stolnik orłowski Rupert Dunin, podczaszy orłowski Stanisław Kożuchowski, wiceinstygator koronny Ignacy Gomoliński oraz pisarz grodzki przedecki Ignacy Jerzmanowski zasłynęli na sejmie z jasno wyrażanych opinii, opozycyjnych w stosunku do kierunku sejmu wyznaczonego przez szefów konfederacji i mocarstwa rozbiorowe. Ich działalność z początku sejmu oraz poparcie protestu Rejtana i Korsaka przyczyniły się do odsunięcia ich od prac delegacyjnych ${ }^{112}$. Już po sejmie rozbiorowym (15 IV 1775) w grodzie warszawskim trzej posłowie łęczyccy: Rupert Dunin, Stanisław Kożuchowski, Franciszek Jerzmanowski oraz poseł łomżyński Tomasz Przyjemski, oblatowali w grodzie warszawskim manifest przeciwko działalności delegacji113.

BC 3373. Aby poznać wydźwięk instrukcji zredagowanej przez Niemojewskiego, wystarczy przytoczyć jej złośliwy wstęp: „Przykładem starodawnych Rzymian, których rząd na wzór Rzeczypospolitej naszej wystawiać lubiemy, sławny w historyi sentyment naśladować nam należy, za którego powodem senat rzymski publiczną konsulowi swemu oświadczył wdzięczność za to jedynie, iż po przegranej na głowę z Annibalem batalii o Rzeczypospolitej nie desperował. Większe daleko dzięki przy najjaśniejszym tronie JKM PNM złożyć nam teraz należy", ibidem.

110 A. Ostrowski do J. Zaremby, 18 III 1773, BK 2120. Nie udało się ustalić, o jakim komisarstwie pisał biskup.

${ }^{111}$ M. Radoszewski do J. Zaremby, 10 IV 1773, BK 2120.

112 W skład delegacji sejmowej wszedł początkowo jedynie Jerzmanowski, w drugim zagajeniu (po uchwaleniu traktatów cesyjnych) dokooptowano Gomolińskiego, R. Chojecki, Patriotyczna opozycja, s. 552.

113 Tekst manifestu: F. Jerzmanowski, Mowy niektóre z umieszczeniem manifestów względem rozebrania kraju polskiego..., Warszawa 1789, s. 40-43. 
Sejmik w Radziejowie, choć nie znamy jego przebiegu, można uznać za regalistyczny ${ }^{114}$. Z grona obranych tam posłów ${ }^{115}$ największą aktywność sejmową przejawiał skarbnik kowalski i marszałek tego sejmiku Antoni Biesiekierski, przedstawiciel rodziny wiernej Stanisławowi Augustowi, który głośno protestował przeciwko rozbiorom jeszcze w 1775 r. ${ }^{116}$ Podobnie nieznane są wydarzenia z Lipna, gdzie obradowała szlachta ziemi dobrzyńskiej. Na sejmiku dobrzyńskim, którego marszałkiem był łowczy rypiński Józef Chełmicki, wybrano dwóch regalistów: podczaszego dobrzyńskiego Piotra Sumińskiego i podczaszego rypińskiego Damazego Mioduskiego ${ }^{117}$.

W Czersku mandat uzyskał nominat Młodziejowskiego, chorąży piotrkowski Jan Rychłowski, który zjawił się na sejmiku zaopatrzony w listy polecające od kanclerza ${ }^{118}$. Drugim posłem został sędzia ziemski czerski Franciszek Prażmowski, któremu kanclerz zalecał współpracę z Rychłowskim $^{119}$. Maria Czeppe i Elżbieta Orman-Michta podały informację, że Stanisław Sołtyk (bratanek biskupa krakowskiego) mógł być jednym $z$ posłów obranych na rozdwojonym sejmiku ziemi czerskiej ${ }^{120}$. Nie znalazłem w źródłach potwierdzenia informacji o rozdwojeniu tego sejmiku ${ }^{121}$, a młody Sołtyk nie uczestniczył jako poseł w pracach sejmu 1773-1775. Sam biskup krakowski twierdził, że wysłał kasztelanica warszawskiego do Zakroczymia ${ }^{122}$.

114 W duchu regalistycznym utrzymana jest bowiem instrukcja z 22 marca 1773 r., A. Pawiński, Rządy sejmikowe w epoce królów elekcyjnych 1572-1795, t. 5: Lauda i instrukcye, 1733-1795, Warszawa 1888 (Dzieje ziemi kujawskiej oraz akta historyczne do nich służące), s. 269-272.

115 Zgodnie z instrukcją posłami brzesko-kujawskimi byli tamtejsi chorąży Stanisław Dąmbski i podczaszy Kazimierz Rybiński, a posłami inowrocławskimi sędzia ziemski brzesko-kujawski Wacław Przyłubski i Antoni Biesiekierski (u Doroty Dukwicz [Rosja, s. 303-304]: Dąmbski i Biesiekierski jako brzesko-kujawscy, a Przyłubski i Rybiński jako inowrocławscy). Por. także J. Dygdała, Przyłubski Wacław, PSB, t. 29, Wrocław-Warszawa-Kraków 1986, s. 204.

116 W. Konopczyński, A. Wojtkowski, Biesiekierski Antoni Dezydery, PSB, t. 2, s. 88-89.

117 D. Kwiatkowski, Aktywność polityczna szlachty dobrzyńskiej na arenie sejmikowej w latach 1764-1793, „Zapiski Kujawsko-Dobrzyńskie” 18, 2003, s. 26-28, 31, 32.

118 A. Młodziejowski do F. Prażmowskiego, 9 III 1773, AGAD, Varia 15, s. 52-53.

119 A. Młodziejowski do sędziego ziemskiego czerskiego F. Prażmowskiego, [9 III 1773], ibidem, s. 53. Przez Rychłowskiego Młodziejowski wysyłał jeszcze listy nakłaniające do udziału w sejmie do starosty brodnickiego Jakuba Zbierzchowskiego i do kasztelana spycimierskiego Stanisława Rychłowskiego, ibidem, s. 50-51.

${ }^{120}$ M. Czeppe, E. Orman-Michta, Sołtyk Stanisław, PSB, t. 40, s. 425.

121 Również Benoît informował o spokojnym przebiegu tego sejmiku; D. Dukwicz, Rosja, s. 171.

122 Zob. niżej, przyp. 141. 
Spokojny przebieg miał sejmik warszawski, który odbył się w kościele św. Marcina (Augustianów) przy ul. Piwnej. Z chóru świątyni obradom przyglądali się Stackelberg oraz Reviczky, nuncjusz Giuseppe Garampi, a także generałowie pruski Rupert Lentulus i rosyjski Bibikow. Sejmik zagajał kasztelan mazowiecki Teodor Szydłowski, proponując do laski marszałkowskiej burgrabiego grodzkiego warszawskiego Adama Skalskiego. Po obraniu posłów (chorążego warszawskiego Wojciecha Szamockiego i sędziego ziemskiego warszawskiego Zygmunta Staniszewskiego) odczytano deklaracje mocarstw rozbiorowych, wezwania na sąd dla „królobójców” oraz list biskupa Sołtyka zalecający posłom troskę o ojczyznę ${ }^{123}$. Jedynie francuskojęzyczny „Courier du Bas-Rihn” donosił o zakłóceniu tego sejmiku przez pijaną osobę ${ }^{124}$.

Sejmik wyszogrodzki został w pierwszym terminie zerwany przed elekcją marszałka przez Jana Pilichowskiego, który swoje działanie argumentował grą na czas i nadzieją na rozłam w „koncercie dworów”. Ponadto uważał on, że sejmik nie powinien obradować w sytuacji, gdy wielu obywateli (byłych konfederatów barskich) przebywa w niewoli rosyjskiej. W ramach odwetu za zerwanie obrad wojsko rosyjskie miało podwoić kontyngent obowiązkowych furażów i żywności z ziemi wyszogrodzkiej ${ }^{125}$. Jeśli tak się rzeczywiście stało, byłby to kolejny dowód operowania Rosji na terenie, który zgodnie z wcześniejszymi ustaleniami powierzony został „opiece” Prus. Powtórny sejmik wybrał na posłów sędziego ziemskiego wyszogrodzkiego Szymona Miszewskiego i regenta wyszogrodzkiego Floriana Małowiejskiego.

W Liwie podczas powtórnych sejmików posłem został powracający z Petersburga Poniński. Zgromadzeniem kierować mieli Ignacy Cieszowski, Antoni Jaczewski i Dominik Gujski, dobierając Ponińskiemu do poselstwa chorążego liwskiego Ignacego Zielińskiego. Pamiętnikarz Ludwik Cieszkowski odnotował, że jedynie pisarz grodzki i ziemski liwski Michał Cieszkowski odważył się sprzeciwić kandydaturze Ponińskiego. Kuchmistrz zareagował ściągnięciem z Węgrowa komendy wojska rosyjskiego w celu zastraszenia sejmiku ${ }^{126}$.

123 „Gazety Wileńskie” 3 IV 1773, 14; laudum ziemi warszawskiej w Tekach Pawińskiego: BPAU-PANKr, 8349, k. 357r-v. Laudum sejmiku gospodarczego z następnego dnia ustanawiało pensję dla członków sejmu ekstraordynaryjnego po 3 tys. złp, ibidem, k. 361v.-362.

124 P. Ugniewski, op. cit., s. 38.

125 „Ekscerpt z listu z Warszawy pisanego”, LNNBU 571, s. 169; G. Benoît do Fryderyka II, 24 III 1773, GStA PK, 1 HA Rep. 96, nr 52e.

${ }^{126}$ Anonim Podolanin [Ludwik Cieszkowski], Pamiętnik anegdotyczny z czasów Stanisława Augusta, wyd. J.I. Kraszewski, Poznań 1867, s. 92-93. 
Nie odnalazłem źródeł informujących o przebiegu pozostałych sejmików województwa mazowieckiego: wiskiego, zakroczymskiego, ciechanowskiego, łomżyńskiego, różańskiego i nurskiego. Ciężko opisać ich postawę wobec bieżących wydarzeń politycznych na podstawie późniejszej działalności posłów czy ich instrukcji ${ }^{127}$. Już podczas sejmu działaniom Ponińskiego sprzeciwiali się m.in. posłowie z Ciechanowa (stolnik przasnyski Wojciech Pęczkowski i podstoli przasnyski Paweł Rościszewski), miecznik i poseł łomżyński Tomasz Przyjemski oraz podkomorzy i poseł wiski Franciszek Wilczewski. Jednocześnie tę samą Łomżę, z której posłował Przyjemski, reprezentował Antoni Sułkowski, brat Augusta i współpracownik Stackelberga ${ }^{128}$.

Brakuje źródeł opisujących, co wydarzyło się na sejmikach znajdujących się pod kontrolą Prus, które nie obrały posłów, tj. ziemi chełmińskiej, ziemi drohickiej oraz płockim w Raciążu. Nie wiemy też, co stało się na dwóch pozostałych sejmikach województwa podlaskiego - ziemi mielnickiej i bielskiej, gdzie wybrano odpowiednio: podsędka mielnickiego Pawła Siestrzewitowskiego i cześnika mielnickiego Benedykta Tarkowskiego oraz podstarostę grodzkiego bielskiego Wnorowskiego i chorążyca bielskiego Ludwika Kruszewskiego ${ }^{129}$. Brakuje też przekazów źródłowych dotyczących sejmików województwa rawskiego. Większość z tamtejszych posłów nie odznaczyła się na sejmie szczególną aktywnością, z wyjątkiem stolnika i posła sochaczewskiego Adama Lasockiego, który dzięki ożywionej działalności znacznie pomnożył wtedy swój majątek ${ }^{130}$.

127 Chociaż instrukcja ciechanowska jako jedna z nielicznych nie posiadała punktu domagającego się ukarania „królobójców” z 3 listopada 1771 r., to nie możemy posłów ciechanowskich zaliczyć do osób sympatyzujących z przywódcami sejmu, R. Chojecki, Patriotyczna opozycja, s. 550, 557.

${ }^{128}$ W. Konopczyński, Geneza, s. 164-169. O posłach obranych na sejmikach mazowieckich zebranych za powtórnym uniwersałem pisał J. Chęcki (12 IV 1773), że są to „subiecta na wszystko rezolwowane, ile ludzie bene sentientes tej unikali funkcyi”, BJ 6666, k. 192; J. Michalski, Rejtan i dylematy, s. 184.

129 Niewiele też możemy powiedzieć o samych posłach. Tarkowski w $1767 \mathrm{r}$. został uznany przez ówczesnego ambasadora rosyjskiego w Rzeczypospolitej Nikołaja Repnina za osobę wrogą rosyjskim celom, Б.В. Носов, Установление российского господства в Речи Посполитой. 1756-1768 г2., Москва 2004, s. 664. Siestrzewitowski zaś już po przyjeździe na sejm rozbiorowy sprzeciwiał się uleganiu obcej przemocy, R. Chojecki, Patriotyczna opozycja, s. 555. Wnorowski pozostaje trudny do zidentyfikowania, Ryszard Chojecki podaje imię Wojciech (Patriotyczna opozycja, s. 561), Dorota Dukwicz - Albert, identyfikując go jednocześnie jako regenta (Rosja, s. 306), w spisie urzędników podlaskich odnajdujemy jedynie Macieja, regenta grodzkiego brańskiego i tamtejszego miecznika (1771-1790), Urzędnicy, t. 8.

${ }^{130}$ R. Chojecki, Lasocki Adam, PSB, t. 16, Wrocław-Warszawa-Kraków 1971, s. 535-537. 
Źródła pozwalają przypuszczać, że Stackelberg, najbardziej zaangażowany w przygotowanie sejmu, nie zachowywał bierności także wobec zgromadzeń szlacheckich w Koronie. Wspierał pozostałych dyplomatów w działalności okołosejmikowej mimo określonych stref wpływów, co dodatkowo podkreślało wiodącą rolę Rosji w koncercie trzech dworów. Kolejnym dowodem na potwierdzenie tej tezy jest, obok wspomnianych wyżej interwencji rosyjskich w Wyszogrodzie i Liwie, zdanie z listu Stanisława Augusta do Tyzenhauza, w którym król stwierdzał, że Ignacy Massalski, współpracujący z rosyjskim dyplomatą przy organizacji sejmików Wielkiego Księstwa, wysłał także zaufanych Wielkopolan na sejmiki w ich prowincji ${ }^{131}$. Trzeba też zauważyć, że sejmikowi współpracownicy Benoît i Revickiego byli jednocześnie ściśle związani z ambasadą rosyjską, a więc ani Austriak, ani Prusak nie mieli do dyspozycji polityków bezpośrednio oddanych ich dworom ${ }^{132}$. Niemieccy dyplomaci, w odróżnieniu od Stackelberga, nie promowali do funkcji poselskiej konkretnych osób, zakładając - jak już to zostało powiedziane - że kluczową kwestią jest zebranie odpowiedniej liczby posłów i senatorów, umożliwiającej rozpoczęcie sejmu ${ }^{133}$.

\section{Pozostali statyści}

Osobą, która odcisnęła swoje piętno na wydarzeniach z początku 1773 r., jest bez wątpienia biskup krakowski Kajetan Sołtyk. Jego rola w zrywaniu sejmików tego roku została kilkakrotnie podkreślona w pracach Konopczyńskiego. Biskup powrócił do Warszawy 12 lutego 1773 r. (pod koniec obrad rady senatu) w glorii obrońcy wiary i ojczyzny, zwolniony

131 „[Biskup wileński] podjął się w radzie dysponować przyjaciół swoich do poselstwa na sejm następujący. Eodem fine Wielkopolan kilku wyjechało do swych województw", Stanisław August do A. Tyzenhauza 15 III 1773, cyt. za: D. Dukwicz, Rosja, s. 175. Podobne informacje znajdujemy w gazetkach rękopiśmiennych z 25 marca 1773 r., które donosiły z Warszawy, że „jmp. Sztakelberg wyjeżdżającemu do Wielkiej Polski jmp. Gurowskiemu, marszałkowi nadwornemu litewskiemu zalecał, aby starał się o obranie takich posłów, którzyby i cnotliwi byli i stateczni w swoich przedsięwzięciach i zdaniach", BJ 6799, s. 2. Stackelberg już od lutego 1773 r. starał się w Petersburgu o zachęcające do współpracy gratyfikacje finansowe dla wielkopolskich senatorów (Młodziejowskiego, Gurowskiego i Ostrowskiego), D. Dukwicz, Sekretne wydatki rosyjskiej ambasady $w$ Warszawie w latach 1772-1790, w: Gospodarka, społeczeństwo, kultura w dziejach nowożytnych. Studia ofiarowane Pani Profesor Marii Boguckiej, red. A. Karpiński, E. Opaliński, T. Wiślicz, Warszawa 2010, s. 454.

132 D. Dukwicz, Rosja, s. 170.

133 Ibidem, s. 173. 
przez Katarzynę II z zesłania, na którym przebywał od 1767 r. ${ }^{134}$ Stackelberg miał nadzieję wykorzystać go w kampanii sejmikowej. Pierwsze kontakty infułata $\mathrm{z}$ ambasadorami trzech mocarstw zdają się świadczyć o braku zdecydowanej postawy Sołtyka wobec zbliżającego się sejmu. Choć sprzeciwiał się rozbiorowi, to jednocześnie marzył o wykorzystaniu sejmu do wprowadzenia republikańskiego ustroju w Rzeczypospolitej. Dopiero 4 marca (po mszy na św. Kazimierza) biskup powziął decyzję o konieczności zrywania sejmików ${ }^{135}$. $\mathrm{Z}$ jednej strony wysyłał do województw pisma, w których nawoływał do wybrania na zgromadzeniach „mężów największej cnoty, doskonałego oświecenia, a pełnych dojrzałej rady", markując w ten sposób współpracę z zaborcami ${ }^{136}$. Z drugiej, w tym samym czasie spod pióra Sołtyka wyszło 200 listów do przyjaciół, w których informował o zapadłej w Warszawie decyzji, że najbliższy sejm odbędzie się pod węzłem konfederacji (co było w owym czasie tylko przypuszczeniem hierarchy) i będzie procedował pod przymusem. Prosił adresatów, aby byli obecni w swych województwach podczas sejmików i nie dopuszczali do ich dojścia ${ }^{137}$. Niezebranie się sejmu w przewidzianym czasie dałoby, zdaniem biskupa, szanse na reakcję dworów europejskich i wyczekiwaną poprawę koniunktury międzynarodowej.

134 O radości części polskiej magnaterii z powrotu „obrońcy wiary” patrz A. Skałkowski, O cześć imienia polskiego, Lwów-Warszawa 1908, s. 94-98; M. Czeppe, Sołtyk Kajetan, PSB, t. 40, s. 397.

135 „Kopia listu rozsyłanego przez K. Sołtyka do zaufanych osób”, 7 III 1773, BC 3869, s. 151-158; J. Michalski, Rejtan i dylematy, s. 181. Dopiero w kwietniowych listach do Stackelberga stwierdzał, że zawsze był otwarcie przeciwny podziałowi Polski, a zatem sejmowi i sejmikom, K. Rudnicki, Biskup Kajetan Sołtyk 1715-1788, Kraków-Warszawa 1906, s. 198.

136 „Kopia listu JOXcia Imć biskupa krakowskiego na sejmiki przedsejmowe pro die 22 mar. 1773 r. wyznaczone, z Warszawy die 8vo eiusdem pisanego", LNNBU 331, k. 30v; K. Rudnicki, op. cit., s. 195-196.

137 „Niekoniecznie zaś masz się WMWMPan osobiście eksponować, ani mnie jakokolwiek narażać, bo można pod ręką ująć lub przekupić kogo spomiędzy szlachty i nasadzić do zerwania, a dopiero po spełzłym akcie przysłać mi tu do Warszawy manifest do zarzucenia w czasie swym i miejscu potrzebny". Biskupowi zależało na tajemnicy: „nie chciałbym przez najmniejszy ślad tej korespondencyi wpaść u postronnych w podejrzenie, zwłaszcza teraz, gdy dzisiejszy poseł moskiewski, człowiek prawdziwe zacny (który gdyby był na miejscu i za czasów Repnina, nie przyszłoby do tylu scen gwałtownych), zabrał do mnie dosyć dobrą przyjaźń i zaufanie, a nawet w przyszłym względem nas ułożeniu mnie się dokłada”. Zalecał też, aby po przeczytaniu odsyłać listy z powrotem do niego: „Przez tę ostrożność nie będą mnie mieć za co uchwycić, chociażby o tym przyszła do nich jaka pogłoska. Ale to prawda, że ekstraordynaryjną będzie rzeczą, jeżeli się sekret utrzyma więcej dwomaset osób najatendowańszych posłany”, „Kopia listu rozsyłanego przez K. Sołtyka do zaufanych osób”, 7 III 1773, BC 3869, s. 151-158. 
Sołtyk rozsiewał również plotki o możliwości odzyskania zabranych ziem, gdyby tylko Stanisław August pogodził się z barzanami. Król, zdaniem biskupa, odmówił, „ułożywszy sobie być absolutem nad resztą kraju”138. Hierarcha twierdził też, że Czartoryscy, mimo wszelkich perturbacji, tkwią przy monarsze i maczają palce w rozbiorze, teraz zaś doprowadzą sejmiki do skutku, zgodnie z rosyjskimi zaleceniami ${ }^{139}$.

Przebywając w Warszawie, z której wyjechał dopiero 2 kwietnia (a więc na trzy dni przed terminem powtórnych sejmików) ${ }^{140}$, starał się oddziaływać na całą Rzeczpospolitą. Wiemy, że porozsyłał na zjazdy szlacheckie przedstawicieli swojej rodziny. Na sejmik sandomierski do Opatowa wysłał starostę dźwinogrodzkiego Feliksa, do Lublina miecznikiewicza sandomierskiego (zapewne Jana Kantego), do Zakroczymia kasztelanica warszawskiego (najprawdopodobniej Stanisława) ${ }^{141}$. W Litwie sejmiki zrywał Józef Kossakowski, który miał dostać na ten cel od biskupa 1000 czerwonych złotych ${ }^{142}$. Mimo wszystko trudno ocenić, w jakim stopniu zrywanie sejmików w marcu 1773 r. było efektem kampanii Sołtyka, a w jakim była to inicjatywa innych magnatów czy lokalnej szlachty, która nie akceptowała porażki konfederacji barskiej i rozbioru. Wiemy, że Sołtyk chwalił się wydaniem na ten cel 6 tys. dukatów ${ }^{143}$. Cieszył się też, że w terminie pierwszych sejmików nie był podejrzewany o ich potajemne zrywanie, bowiem przypisywano to stronnikom Familii ${ }^{144}$. Reviczky jeszcze w czasie kampanii sejmikowej wyrażał niepokój o dwa czynniki, które mogą przeszkodzić celom politycznym mocarstw:

138 Ibidem.

139 „Zawsze zaś tego się można dorozumieć, że wchodzili w te wszystkie ułożenia i projekta podziału naszej Polski. Daje się to widzieć z owego komplementu od posła rosyjskiego książęciu wojewodzie ruskiemu [A. Czartoryskiemu] uczynionego, że jakoby byli początkiem tych okoliczności w kraju naszym, tak mają się starać, ażeby posłowie na teraźniejszych sejmikach stanęli powolni do interesów jego dworu. Od czego, gdyby się chcieli usuwać, będą wzięci za łeb wraz z królem", ibidem.

140 J. Michalski, Rejtan i dylematy, s. 181.

141 „Kontynuacja dalszych uwiadomień, które Sołtyk posłał przez sztafetę”, BC 3869, s. 153-158.

${ }^{142}$ Pamiętniki Józefa Kossakowskiego biskupa inflanckiego 1738-1788 z portretem, wyd. A. Darowski, Warszawa 1891, s. 76.

${ }^{143}$ K.E. Reviczky do W.A. Kaunitza, 17 IV 1773, HHStA, Polen II, 35 (I-III 1773), k. $93 \mathrm{v}$.

144 „Łaska boska, że to, co ja robię aktualnie do przyszłych sejmików, to przypisują królowi i Familii, i posłowie cudzoziemscy odgrażają się, że gdy to nastąpi, to i jego, i Familię za łeb wezmą", cyt za: K. Rudnicki, op. cit., s. 196. Sam Reviczky po pierwszej turze sejmików uważał, że zerwanie kilku prowincjonalnych sejmików przypisuje się królowi, który miał zachęcać szlachtę do gry na zwłokę, K.E. Reviczky do W.A. Kaunitza, 31 III 1773, ibidem, k. 241v-242. 
oczekiwany w Warszawie Plan Panina na sejm i woltę ze strony Sołtyka ${ }^{145}$. Współcześni zaś zaczęli już zauważać w owym czasie początki choroby psychicznej biskupa ${ }^{146}$.

Inną osobą działającą na terenach koronnych był zaprzedany Sasom, a uznawany przez Revickiego za stronnika pruskiego, kasztelan łęczycki Tadeusz Lipski. Rozesłał on na sejmiki własne propozycje punktów do instrukcji poselskich. Ograniczały się one do żądania ewakuacji wojsk zagranicznych, nieuznawania zaborów, niedopuszczania dysydentów do funkcji poselskich oraz starań o awans dla odwołanego z Polski nuncjusza Angela Duriniego, pod groźbą nieuznawania jego następcy ${ }^{147}$. Nie wiemy, do których sejmików dotarły punkty Lipskiego, gdyż żadna ze znanych nam instrukcji nie zawiera punktu dotyczącego wysłannika Watykanu.

Część sejmików 1773 r., rozchodzących się bez obrania posłów, wydawała manifesty. Protesty te były oblatowane przez szlachtę $\mathrm{w}$ grodach, a następnie kolportowane po Rzeczypospolitej jako wyraz oporu. Takie dokumenty rozpowszechniły sejmiki: sandomierski, żmudzki, kijowski, wołyński oraz czernihowski ${ }^{148}$. Wojciech Jakubowski informował, że pod manifestem kijowskim podpisało się 120 zgromadzonych na sejmiku

145 „Ich nur zwei Hindernisse erblicke, welche dem für den allerhöchsten kaiserl.-königl. Hof erwünschlichen Ausschlag und Endschaft der Sachen im Wegen liegen könnten. Diese etwainige Hindernisse sind: die zur Unzeit geschehene Ruckkehr des Bischofs von Krakau aus seinem Verweisungsort und der anjetzo von Russland entworfene Plan, besonders wenn letzterer ohne Abänderung verbleibet. Es ist unschwer in demselben jene mit Leidenschaft angefüllte und der Ordnung und Ruhe so entgegengesetze Hand wahrzunehmen, welche diesem Plan die Leitung gegeben. Was dabei am meisten zu bedauren scheinet, ist, dass dem Freiherrn von Stackelberg der eine so billige Neigung zur Herstellung eines wahren und festen Ruhestandes in Polen gezeiget hat, durch die Verkehrungen des Russischen Plans die Hände nunmehro gebunden sind", K.E. Reviczky do W.A. Kaunitza, 8 III 1773, ibidem, k. 188v.

146 „Soli. Książę biskup [--] na asamblach u siebie extravagantias robił z zdrowym rozumem nie zgadzające się. Przyjaciele jego starali się nagle stąd go uprowadzić", J.N. Chęcki do A. Chmary, 5 IV 1773, BJ 6666, k. 191v.

147 „Instrukcja krótka na sejmiki od Lipskiego kasztelana łęczyckiego po województwach rozesłana 22 lutego", BJ 6674, s. 110. O odwołaniu Duriniego zob. W. Konopczyński, Konfederacja barska, t. 2, s. 623; D. Dukwicz, Rosja, s. 42-43.

${ }^{148}$ Teksty manifestów znajdują się w BPAU-PANKr 320, liczne odpisy są w innych sylwach. Manifest kijowski znalazł się w korespondencji dyplomatycznej nuncjusza Garampiego, Vetera monumenta Poloniae et Lithuaniae gentiumque finitimarum historiam illustrantia. Maximam partem nondum edita ex tabularis Vaticanis deprompta collecta ac serie chronologica disposita, t. 4: Ab Innocentio PP. XII. usque ad Pium PP. VI. 1697-1775, cz. 2, wyd. A. Theiner, Romae 1864, s. 468; o manifeście księstwa żmudzkiego: J. Michalski, Rejtan $i$ dylematy, s. 184; o sandomierskim: G. Benoît do Fryderyka II, 24 III 1773, GStA PK, 1 HA Rep. 96, nr 52e. 
szlachciców, pod wołyńskim miało się znaleźć 150 podpisów ${ }^{149}$. Manifesty podnosiły nielegalność zjazdów szlacheckich wobec obecności obcych wojsk. Szlachta stwierdzała też, że nie ma prawa pozwolić na sejmie na rozbiór kraju. Protestowała nadto przeciwko więzieniu współobywateli, przebywających w aresztach mocarstw ościennych. Współcześni uważali manifesty 1773 r. za nowość w dziejach Rzeczypospolitej, ze względu na to, iż apriorycznie zakładały nielegalność zbliżającego się sejmu i jego postanowień ${ }^{150}$. Przed drugimi sejmikami posłowie mocarstw rozbiorowych mieli wydać tajną instrukcję zakazującą przyjmowania w grodach podobnych protestacji ${ }^{151}$. Nie znalazłem jednak na to dostatecznie pewnych dowodów źródłowych.

W historiografii polskiej utrwalony jest pogląd o spokojnym przebiegu sejmików 1773 r. ${ }^{152}$ Obecność obcych wojsk, która stanowiła realne zagrożenie dla sejmikujących i ich majątków, miała skutecznie ów spokój wymusić. Tam, gdzie sejmiki się rozeszły, szlachta, po wpisaniu do ksiąg grodzkich manifestów, rozjeżdżała się do domów. Przekonanie o spokoju bierze się z braku opisów krwawego przebiegu sejmików w źródłach pochodzących z najważniejszych zwodów korespondencji oraz w relacjach dyplomatów mocarstw rozbiorowych, którym notabene wcale nie zależało na informowaniu swoich mocodawców o rozruchach na sejmikach, gdyż mogłoby to wskazywać na nieskuteczność ich działań. O incydentach donoszą jednak gazety zagraniczne oraz źródła mniejszej wagi. Nieoficjalny rezydent francuski Jean-Claude Gérault wspominał o dobywaniu szabel i strzelaninach, w "Gazette de France” pisano o walce na szable, która mogła sejmik wiłkomierski przemienić w masakrę, i o 30 rannych lub zabitych na sejmiku łęczyckim ${ }^{153}$. Anonimowy

149 P. Ugniewski, op. cit., s. 40-41.

150 „Z kijowskiego i wołyńskiego województw piszą, iż tam obywatele nie tylko sejmiku nie dopuścili, ale też manifest zanieśli przeciw temu wszystkiemu, cokolwiek na następującym sejmie ułożą, co lubo jest nowym i jeszcze niepraktykowanym w rządzie Rzeczypospolitej naszej przykładem. Jednak teraz jest dobrze wymyślonym, potrzebnym i być może użytecznym. Pierwszy bowiem też przykład, aby Rzeczpospolita pod bronią trzech wojsk zagranicznych swe odprawiała sejmy. Przeto, gdy wyraźnie zabrania prawo pod wodzą wojsk obecnych sejmować, tedy i manifesta sejm taki poprzedzające mogą wczesną przeciw uciskom pod tąż mocą wypadłych zarzucać tamę i nieważność onych ogłaszać. Podobnym przeciw rzeczonemu sejmowi (jak głoszą) i wszystkich na nim ustawom zanieść miał manifest ks. imć prymas do akt starego miasta Gdańska", „Wiadomości z Warszawy 15 kwietnia”, BJ 6674, s. 149-150. Nie jestem w stanie potwierdzić, czy pogłoska o prymasowskiej protestacji jest prawdziwa.

151 P. Ugniewski, op. cit., s. 39.

152 J. Michalski, Rejtan i dylematy, s. 183.

153 P. Ugniewski, op. cit., s. 39, 42, 43. 
i niedatowany list opisujący przebieg sejmików poselskich znajdujący się w zbiorze korespondencji Jerzego Mniszcha informuje, że doszły jedynie sejmiki, „gdzie się mogli subiekta od Warszawy zalecone podtrzymywać" oraz że nie dopuszczano do godności poselskiej przyjaciół biskupa krakowskiego. Taka wiadomość jest zapewne odbiciem nastrojów antykrólewskich, które nakazywały wierzyć, że Stanisław August działa w porozumieniu z zaborcami. Sejmiki w Zakroczymiu i Wyszogrodzie - zgodnie $z$ tą relacją - miały zostać oprotestowane przez przedstawicieli rodziny Pilichowskich, wziętych następnie w areszt ${ }^{154}$. Inne gazetki donoszą, że aresztanci zostali wypuszczeni dopiero po interwencji biskupa krakowskiego i kasztelana łęczyckiego Tadeusza Lipskiego ${ }^{155}$. Pisano też, że do szabel miała się porwać szlachta „w Liwie, w Ciechanowie i po innych miejscach". Autor tej relacji - ewidentny kolekcjoner plotek - przekazywał jednocześnie pogłoski o nowych buntach chłopskich na Ukrainie i zmyślone wieści z frontu rosyjsko-tureckiego, których w owym czasie krążyły tysiące po wszystkich regionach Rzeczypospolitej ${ }^{156}$.

\section{Wynik sejmików}

Wydarzenia z marca i kwietnia 1773 r. pokazują, że szlachta prowincjonalna, która pod koniec lat sześćdziesiątych w dużej mierze sympatyzowała z ruchem barskim, zaczęła dostrzegać spustoszenie kraju spowodowane pięcioletnią wojną i marzyła przede wszystkim o ewakuacji wojsk zagranicznych. Zaczęła także docierać do niej świadomość, że jedynie sejm może przywrócić spokój w kraju poprzez zaspokojenie żądań trzech mocarstw. Więc chociaż początkowo do uczestnictwa w sejmie podchodzono z dużą rezerwą, wraz ze zbliżaniem się sejmików dochodzono do przekonania, że „lepiej mieć sejm, niż rozebrany do ostatka kraj”157.

154 List Sołtyka zachęcający do zerwania sejmiku zakroczymskiego mieli przechwycić Rosjanie: de Boulloir do księcia d'Aiguillion, 13 IV 1773, BC 1997. Sam Sołtyk twierdził, że wysłał tam kasztelanica warszawskiego, żeby forsował jego stanowisko; por. wyżej, przyp. 141. Jednak, jak chwalił się Benoît, sejmik ten miał przebiec bardzo spokojnie: „Je commence à recervoir de bonnes nouvelles du succès des diéttines dont j'ai pris le soin sur moi. Telles sont celles de Varsovie, de Czersk et de Zakroczym, qui ont fort bien réussies, et où les nonces pour la prochaine diètte ont été fort tranquillement élus", G. Benoît do Fryderyka II, 24 III 1773, GStA PK, 1 HA Rep. 96, nr 52e.

155 Doniesienia z Warszawy z dn. 1 IV 1773, BJ 6674, s. 145.

156 NN do J. Mniszcha, b.d., BC 3869.

157 Tak o wzroście świadomości szlachty pisał Stanisław August do Tyzenhauza, 15 III 1773, BC 715, s. 211. W podobnym duchu napisana została preambuła do instrukcji nowogródzkiej: „Czas przeto teraźniejszy, gdy w ekstraordynaryjnych przypadkach jest 
Zgromadzenia szlacheckie wprowadziły do izby poselskiej sporo postaci niesprawujących wcześniej mandatu poselskiego. Instrukcje, w które wyposażono posłów, nie zawierały zbyt wielu konkretnych zaleceń, co spowodowane było niepewnością sytuacji politycznej. Posłowie jechali do Warszawy, nie wiedząc, czy zbliżający się sejm będzie obradował jako wolny (jak to było ogłoszone w uniwersale), czy pod węzłem konfederacji (o czym przekonana była duża część szlacheckiej opinii publicznej $\left.{ }^{158}\right)$. Szlachtę w tym czasie interesowało przede wszystkim określenie granic okrojonej Rzeczypospolitej, a realizm nakazywał godzić się na rozbiór. Powszechnym życzeniem było wyjście z kraju wojsk rozbiorowych, które siały spustoszenie w miejscach stacjonowania. Obywatelom dawał się też we znaki brak podstawowych produktów, w tym przede wszystkim soli z zagarniętych przez Austrię salin. Istotną kwestią dla wielu pozostawała obrona prerogatyw Kościoła rzymskiego, naruszonych przez Rosjan podczas ostatniego sejmu. Szlachta z jednej strony dbała tu o sprawy boskie, z drugiej wiązała z Kościołem interesy doczesne, jak np. darmowe szkolnictwo zakonne dla młodzieży szlacheckiej czy partycypacja duchowieństwa w kosztach utrzymania państwa. Jedynie bezpieczni ekonomicznie magnaci mogli snuć marzenia o pogłębieniu republikańskiego charakteru ustroju i przyjmować jego ustanowienie jako kluczową misję sejmu 1773-1775. Mieli w tym zresztą milczące poparcie hołdującej republikanizmowi części społeczeństwa szlacheckiego ${ }^{159}$.

ekstraordynaryjne sejmowanie wymuszającym, na sejmik one poprzedzający zgromadzeni bierzemy przed się w oświeceniu obywatelskich obowiązków przekonywające nas sentymenta, nie chcący iść za naślednictwem sług niedobrych, którzy patrząc się na pożar domu pana swego, ręce załamawszy chodzą. Im w nieszczęśliwościach barziej pogrążoną widzimy Rzeczpospolitą, tym w troskliwościach nad nią i w samej gorliwej tylko rozpaczy, z oddzielności partykularnego życzenia żadnych ojczyźnie pomyślnych nie upatrując skutków, cel zagrodzenia zranionemu i rozerwanemu ciału Rzeczypospolitej, ustanowienie niejakich na wszystkie okoliczności bacznych przestróg, zabiegów i czynności, zaratowanie od przepaści anarchicznej w mocy wolnego sejmowania zakładamy, a przeto w czystości ducha obywatelskiego sejmikujących, wysłanie posłów na sejm przyszły zadeterminowaliśmy", BPAU-PANKr 1155. Por. także: D. Dukwicz, Czy rozbiór był wstrzasem? Problem reakcji społeczeństwa szlacheckiego Rzeczypospolitej na zabór części terytorium oraz utratę suwerenności w okresie pierwszego rozbioru, w: „My i oni”. Społeczeństwo nowożytnej Rzeczypospolitej wobec państwa, red. W. Kriegseisen, Warszawa 2016, s. 364-365.

158 Mocarstwa rozbiorowe podjęły co prawda decyzję o skonfederowaniu sejmu rozbiorowego już w lecie 1772 r., jednak plany te nie zostały ujawnione Polakom, J. Michalski, Rejtan i dylematy, s. 187.

159 Zestawienie głównych postulatów szlacheckich na podstawie 18 instrukcji poselskich sporządził Jerzy Michalski (Rejtan i dylematy, s. 184-186), znane mu były instrukcje: województw kujawskich (A. Pawiński, op. cit., s. 269-272), ziemi dobrzyńskiej 
Analiza kampanii wyborczej z wiosny $1773 \mathrm{r}$. pozwala na stworzenie nieco innego obrazu wydarzeń niż ten, który w swych monografiach zarysowywał Konopczyński. Wbrew stwierdzeniu wybitnego badacza, że „sejmiki odbyły się ze strony polskiej bez pozytywnego kierownictwa"160, w Wielkim Księstwie Litewskim mamy uchwytne potwierdzenia wspólnej okołosejmikowej działalności Stanisława Augusta i podskarbiego Tyzenhauza. W świetle moich badań zakwestionować mogę więc sformułowanie Stanisława Kościałkowskiego, który pisał, że „sejmiki poselskie z roku 1773 [--] do czasu wielkiej roli Tyzenhauza nie należą, stoją już poza jego agitacją polityczną na Litwie i bez jego wpływów się odbywały"161. Powtarzam więc tezę Doroty Dukwicz, że kampania poselska 1773 r. stanowi pierwszy akord tworzenia stronnictwa królewskiego na Litwie ${ }^{162}$. Dla Stanisława Augusta było to koniecznością wobec odsunięcia od udziału we władzy Czartoryskich, z których klienteli król dotąd korzystał. Dla Korony możemy wyciągać ostrożne przypuszczenia, co do monarszej działalności, wnioskując z wyników sejmików i liczby prokrólewskich posłów, którą na sejmie zauważali dyplomaci zagraniczni ${ }^{163}$.

(Lauda sejmików ziemi dobrzyńskiej, wyd. F. Kluczycki, Kraków 1887, s. 377-378), województw wielkopolskich, krakowskiego, łęczyckiego, brzesko-litewskiego, powiatu wołkowyskiego - AGAD, Zbiór Popielów 123; województwa nowogródzkiego - BPAU-PANKr 1155; ziemi wyszogrodzkiej - BPAU-PANKr 1089 , ziemi ciechanowskiej - BPAU-PANKr 8318, czerskiej - BPAU-PANKr 8320, liwskiej - BPAU-PANKr 8322, łomżyńskiej - BPAU-PANKr 8332, nurskiej - BPAU-PANKr 8335, różańskiej - BPAU-PANKr 8337, sochaczewskiej - BPAU-PANKr 8347, wiskiej - BPAU-PANKr 8350 i zakroczymskiej - BPAU-PANKr 8354. Kwerenda w LVIA pozwoliła odnaleźć dodatkowe trzy instrukcje: wileńską i starodubowską - SA 4787 oraz trocką - SA 5917; w Narodowym Archiwum Historycznym Białorusi w Mińsku znajdują się jeszcze cztery: pińska - f. 1733, j. 51, mińska - f. 1727, op. 1, j. 16, mozyrska - f. 1728, op. 1, j. 17 i grodzieńska - f. 1711, op. 1 (ta została ogłoszona drukiem w: Akty Izdawajemyje Wilenskoju Archeograficzeskoju Komissieju, t. 6, Wilna 1874, s. 374-383). Instrukcja ziemi wieluńskiej znajduje się natomiast w BC 3373. Poszerzona baza źródłowa nie zmienia jednak zasadniczych ustaleń Michalskiego.

160 W. Konopczyński, Konfederacja barska, t. 2, s. 706.

161 S. Kościałkowski, op. cit., s. 129. Podobnie na s. 96: „W czasie sejmików poselskich przedsejmowych [1773 r.] rozwija Tyzenhauz działalność tylko w powiecie grodzieńskim i jedynie na sejmiku tego powiatu spełnia z powodzeniem wolę królewską".

162 D. Dukwicz, Rosja, s. 177.

163 Sekretarz poselstwa saskiego Johann Jakob Patz twierdził, że podczas kampanii poselskiej w imieniu króla działali kasztelan biecki Wojciech Kluszewski oraz kasztelan raciąski Jan Krajewski, J. Michalski, Rejtan i dylematy, s. 182. Natomiast Reviczky, obserwując wynik wyborów, wyrażał niezadowolenie, że większość posłów pochodzi z królewskiej nominacji, D. Dukwicz, Rosja, s. 178. 
W świetle przedstawionych źródeł można się też pokusić o próbę podważenia sformułowania o całkowitej bierności Czartoryskich podczas kampanii sejmikowej, czego dowodem są wydarzenia sejmików podolskiego i nowogródzkiego. Spośród zagranicznych dyplomatów mocne zaangażowanie $\mathrm{w}$ tej kwestii wykazał jedynie Stackelberg, który jako reprezentant dominującego w Rzeczypospolitej mocarstwa starał się o sukces sejmików zarówno w Wielkim Księstwie, jak i w Koronie (choć mniej ostentacyjnie). Dyplomaci niemieccy ograniczyli swe działania do niezbędnego minimum, tj. utrzymania atmosfery terroru, przejmując się raczej dojściem sejmików, niż ich wynikiem mierzonym przynależnością polityczną posłów i treścią instrukcji.

Źródła zdają się potwierdzać konstatację Michalskiego o generalnie spokojnym przebiegu zgromadzeń, co nie oznacza, że obyły się one bez incydentów. Zachowanie szlachty polskiej podczas obrad sejmikowych wynikało zapewne z poczucia zagrożenia ze strony stacjonujących w kraju żołnierzy państw rozbiorowych. Wojska natomiast ograniczyły swoją działalność do rozsiewania gróźb z zachowaniem pozoru wolności sejmikowania i zasadniczo nie ingerowały w przebieg sejmików w sposób tak bezpardonowy, w jaki będą interweniowały podczas wyborów poselskich na sejm $1776 \mathrm{r}$.

Wydaje się, że nawet dla współczesnych nie było oczywiste, czego należy się spodziewać po obranej w 1773 r. izbie poselskiej. Dopiero protest Rejtana przeciwko konfederacji sejmowej i wynik ważnego głosowania nad formą delegacji sejmowej z 14 maja $1773 \mathrm{r}$. pokazały, kto będzie stanowił opozycję dla wspieranych przez sąsiedzkich dyplomatów przywódców sejmu. Skład osobowy parlamentu, jaki ukształtował się w wyników wyborów sejmikowych, został po 14 maja okrojony. Panin zalecił bowiem wyłonienie pełnomocnej delegacji na wzór sejmu $1767 \mathrm{r}$. do opracowania traktatów rozbiorowych i konstytucji sejmowych. Stackelberg przy niewielkim udziale Stanisława Augusta zdecydował, kto weźmie faktyczny udział w pracach legislacyjnych, a marcowe i kwietniowe sejmiki dały jedynie ambasadorowi do ręki pulę kart, którą posługiwał się w tej rozgrywce.

\section{Streszczenie}

Przedmiotem artykułu są działania polityczne prowadzone na początku $1773 \mathrm{r}$. oraz przygotowania do sejmu, do głównych zadań którego należało zaakceptowanie pretensji terytorialnych mocarstw rozbiorowych i reforma ustroju Rzeczypospolitej. W związku z dekompozycją polskiej sceny politycznej po upadku konfederacji 
barskiej i zmianą rosyjskiej polityki wobec Rzeczypospolitej (przejawiającej się m.in. w zmianie szefa rosyjskiej placówki dyplomatycznej w Warszawie) sejmiki poselskie $1773 \mathrm{r}$. stały się areną kształtowania nowej elity politycznej oraz próbą sił między Stanisławem Augustem, zagranicznymi dyplomatami i antykrólewską opozycją. Analiza ta pozwala przesunąć wstecz początek starań Stanisława Augusta o pozyskanie własnego stronnictwa, co pozwoliłoby mu na sprawowanie rządów po odsunięciu od władzy Czartoryskich, na których związkach klientarnych opierał się w pierwszych latach swego panowania.

Autor na podstawie relacji zagranicznych dyplomatów i rozproszonych źródeł krajowych stara się odtworzyć przebieg działań sejmikowych z marca i kwietnia 1773 r., zwracając szczególną uwagę na wpływy dworu Stanisława Augusta oraz posłów Rosji, Prus i Austrii. Chociaż trzej dyplomaci działali w ramach ustalonych wcześniej stref wpływów, to zauważalne jest dążenie rosyjskiego dyplomaty Ottona Magnusa von Stackelberga do zadbania o realizację postulatów mocarstw rozbiorowych także na terenach poddanych kontroli dyplomatów niemieckich.

Prześledzenie działań politycznych kampanii sejmikowej 1773 r. pokazuje pierwszy test sprawności politycznej Stackelberga, który od tego momentu będzie grał pierwsze skrzypce w polityce Rzeczypospolitej do okresu Sejmu Wielkiego i załamania się rosyjskiej protekcji nad państwem polsko-litewskim.

\section{The Struggle over the Composition of the 1773-1775 Sejm}

The article deals with political activities at the beginning of 1773 and the preparation for the Sejm whose main goal was to accept the territorial claims of the partitioning powers and to reform the political system of the Commonwealth. Due to the decomposition of the Polish political scene after the fall of the Bar Confederation and the changes in Russian policy towards the Commonwealth (manifesting themselves, among other things, in the change of the head of the Russian diplomatic post in Warsaw), the 1773 sejmiks to elect parliamentary envoys became an arena for shaping a new political elite and a tug-of-war between King Stanisław August, foreign diplomats, and the anti-royal opposition. The analysis makes it possible to move back the beginnings of King Stanisław August's efforts to create his own party that would allow him to reign more autonomously, after the Czartoryskis, on whose clientage network he had relied in the first years of his reign, were removed from power.

Based on the accounts of foreign diplomats and dispersed Polish sources, the author tries to reconstruct the course of events related to the sejmiks in March and April 1773, with particular attention paid to the influences of King Stanisław August's court and the representatives of Russia, Prussia, and Austria in Poland. Although the three diplomats operated within established spheres of influence, there are quite visible efforts of the Russian diplomat, Otto Magnus von Stackelberg, who wanted to ensure that the postulates of the partitioning powers were also implemented in the territories under the control of the two German diplomats. 
The examination of the political developments of the 1773 parliamentary election campaign reveals the first test of Stackelberg's political acumen, who would play first fiddle in the policy of the Commonwealth until the Four Years' Sejm and the collapse of Russian protection over the Polish-Lithuanian state.

\section{Bibliografia}

Akty Izdawajemyje Wilenskoju Archeograficzeskoju Komissieju, t. 6, Wilna 1874.

Anonim Podolanin [Ludwik Cieszkowski], Pamiętnik anegdotyczny z czasów Stanisława Augusta, wyd. Józef Ignacy Kraszewski, nakł. Księgarni Jana Konstantego Żupańskiego, Poznań 1867.

Burda-Ricklefs Elżbieta, Sołtyk Tomasz, PSB, t. 40, Warszawa-Kraków 2000-2001, s. 435-436.

Chojecki Ryszard, Lasocki Adam, PSB, t. 16, Wrocław-Warszawa-Kraków 1971, s. 535-537.

Chojecki Ryszard, Patriotyczna opozycja na sejmie 1773 r., „Kwartalnik Historyczny” 79, 1972, 3, s. 545-562.

Czeppe Maria, Orman-Michta Elżbieta, Sołtyk Stanisław, PSB, t. 40, Warszawa-Kraków 2000-2001, s. 424-431.

Czeppe Maria, Sołtyk Kajetan, PSB, t. 40, Warszawa-Kraków 2000-2001, s. 386-404. Dukwicz Dorota, Czy rozbiór był wstrzasem? Problem reakcji społeczeństwa szlacheckiego Rzeczypospolitej na zabór części terytorium oraz utratę suwerenności w okresie pierwszego rozbioru, w: „My i oni”. Społeczeństwo nowożytnej Rzeczypospolitej wobec państwa, red. Wojciech Kriegseisen, IH PAN, Warszawa 2016, s. 355-377.

Dukwicz Dorota, Kilka słów na temat historiografii pierwszego rozbioru, w: W. Konopczyński, Pierwszy rozbiór Polski, [red. Zofia Zielińska], Arcana, Kraków 2010, s. XLVII-LI.

Dukwicz Dorota, Rosja wobec sejmu rozbiorowego warszawskiego (1772-1775), IH PAN, Warszawa 2015.

Dukwicz Dorota, Sekretne wydatki rosyjskiej ambasady w Warszawie w latach 1772-1790, w: Gospodarka, społeczeństwo, kultura w dziejach nowożytnych. Studia ofiarowane Pani Profesor Marii Boguckiej, red. Andrzej Karpiński, Edward Opaliński, Tomasz Wiślicz, DiG, Warszawa 2010, s. 449-465.

Dukwicz Dorota, Zwierzykowski Michał, Sułkowski August, PSB, t. 45, WarszawaKraków 2007-2008, s. 542-553.

Dygdała Jerzy, Przyłubski Wacław, PSB, t. 29, Wrocław-Warszawa-Kraków 1986, s. 204. Filipczak Witold, Życie sejmikowe prowincji wielkopolskiej w latach 1780-1786, Wydawnictwo UŁ, Łódź 2012.

Goliński Zbigniew, Kalendarz życia i twórczości Ignacego Krasickiego, Wydawnictwo PTPN, Poznań 2011.

Goliński Zbigniew, Krasicki Ignacy, PSB, t. 15, Wrocław-Warszawa-Kraków 1970, s. $144-150$.

Jerzmanowski Franciszek, Mowy niektóre z umieszczeniem manifestów względem rozebrania kraju polskiego..., Warszawa 1789. 
Jusupović Monika, Prowincjonalna elita litewska w XVIII wieku. Działalność polityczna rodziny Zabiełłów w latach 1733-1795, IH PAN, Neriton, Warszawa 2014.

Kobierecki Michał, Walewscy herbu Kolumna w XVII-XVIII wieku. Genealogia. Majętności. Działalność publiczna, Ibidem, Łódź 2008.

Konopczyński Władysław, Borzysławski vel Borysławski Antoni Marcin, PSB, t. 2, Kraków 1936, s. 371-372.

Konopczyński Władysław, Czacki Feliks (Szczęsny), PSB, t. 4, Warszawa-Kraków-Łódź 1938, s. $140-142$.

Konopczyński Władysław, Dembiński Stanisław Kostka, PSB, t. 5, Warszawa-KrakówŁódź 1939-1946, s. 75.

Konopczyński Władysław, Geneza i ustanowienie Rady Nieustajacej, Akademia Umiejętności, Kraków 1917.

Konopczyński Władysław, Kiedy nami rządziły kobiety, Veritas, Londyn 1960.

Konopczyński Władysław, Konfederacja barska, t. 1-2, Volumen, Warszawa 1991.

Konopczyński Władysław, Pierwszy rozbiór Polski, [red. Zofia Zielińska], Arcana, Kraków 2010.

Konopczyński Władysław, Stanisław Konarski, Wyd. Kasa im. Mianowskiego - Instytut Popierania Nauki, Warszawa 1926.

Konopczyński Władysław, Wojtkowski Andrzej, Biesiekierski Antoni Dezydery, PSB, t. 2, Kraków 1936, s. 88-89.

Kosińska Urszula, rec.: Dorota Dukwicz, Rosja wobec sejmu rozbiorowego warszawskiego (1772-1775), Instytut Historii PAN, Warszawa 2015, „Biblioteka Epoki Nowożytnej" 2016, 1, s. 207-214.

Pamiętniki Józefa Kossakowskiego biskupa inflanckiego 1738-1788 z portretem, wyd. Adam Darowski, skł. gł. w Księgarni Gebethnera i Wolffa, Warszawa 1891.

Kościałkowski Stanisław, Antoni Tyzenhauz. Podskarbi nadworny litewski, t. 1, Wydaw. Społeczności Akademickiej Uniwersytetu Stefana Batorego, Londyn 1970.

Kriegseisen Wojciech, Sejmiki Rzeczypospolitej szlacheckiej w XVII i XVIII wieku, Wydawnictwo Sejmowe, Warszawa 1991.

Kuras Katarzyna, Wspótpracownicy i klienci Augusta A. Czartoryskiego w czasach saskich, Historia Iagellonica, Kraków 2010.

Kwiatkowski Dariusz, Aktywność polityczna szlachty dobrzyńskiej na arenie sejmikowej w latach 1764-1793, „Zapiski Kujawsko-Dobrzyńskie” 18, 2003, s. 13-32.

Lauda sejmików ziemi dobrzyńskiej, wyd. Franciszek Kluczycki, nakł. Akademii Umiejętności Krakowskiej, Kraków 1887.

Michalski Jerzy, Historiografia polska wobec problematyki pierwszego rozbioru, w: idem, Studia historyczne z XVIII i XIX wieku, t. 2: Ideologia, nauka, historiografia, [red. nauk. Wojciech Kriegseisen, Zofia Zielińska], Stentor, Warszawa 2007, s. 496-508.

Michalski Jerzy, Rejtan i dylematy Polaków w dobie pierwszego rozbioru, w: idem, Studia historyczne z XVIII i XIX wieku, t. 1: Polityka i społeczeństwo, [red. nauk. Wojciech Kriegseisen, Zofia Zielińska], Stentor, Warszawa 2007, s. 160-201.

Michalski Jerzy, Reytan (Rejtan, Reyten) Tadeusz, PSB, t. 31, Wrocław-Warszawa-Kraków 1988-1989, s. 231-237.

Modelski Teofil Emil, Wywód ks. Kaunitza z r. 1772 o pierwszym podziale Polski, „Kwartalnik Historyczny" 31, 1917, 1, s. 55-106. 
Ostrożyński Władysław, Sprawa zamachu na Stanisława Augusta z 3 listopada 1771 przed sądem sejmowym, drukiem i nakładem drukarni Wł. Łozińskiego, Lwów 1891.

Pawiński Adolf, Rządy sejmikowe w epoce królów elekcyjnych 1572-1795, t. 5: Lauda $i$ instrukcye, 1733-1795, Warszawa 1888 (Dzieje ziemi kujawskiej oraz akta historyczne do nich służące).

Romaniuk Przemysław Piotr, Sołłohub Józef Antoni, PSB, t. 40, Warszawa-Kraków 2000-2001, s. 319-323.

Rostworowski Emanuel, Judycki Józef, PSB, t. 11, Wrocław-Warszawa-Kraków 1964, s. 311-314.

Rudnicki Kazimierz, Biskup Kajetan Sołtyk 1715-1788, skł. gł. w Księgarni Gebethnera i Wolffa, Kraków-Warszawa 1906.

Schmitt Henryk, Źródła odnoszące się do pierwszego okresu panowania Stanisława Augusta po rok 1773, nakładem autora, Lwów 1884.

Skałkowski Adam, O cześć imienia polskiego, Towarzystwo Wydawnicze: H. Altenberg, E. Wende i Spółka, Lwów-Warszawa 1908.

Skowroński Piotr, „Trudno przeciw wodzie płynace”. Ignacy Twardowski $w$ okresie I rozbioru Polski, w: Zmierzch i świt. Stanisław August i Rzeczpospolita 1764-1795, red. Aleksandra Antoniewicz, Rozalia Kosińska, Piotr Skowroński, Neriton, Warszawa 2015, s. 155-169.

Stynne kobiety w Rzeczypospolitej XVIII wieku, red. Agata Roćko, Magdalena Górska, Muzeum Pałacu Króla Jana III Sobieskiego w Wilanowie, Warszawa 2017.

Srogosz Tadeusz, Początki budowy stronnictwa królewskiego na Ukrainie przez Józefa Gabriela Stempkowskiego (koniec lat sześćdziesiątych - początek siedemdziesiatych XVIII w.), „Przegląd Nauk Historycznych” 5, 2006, 1, s. 171-183.

Stanislas Auguste, Mémoires, wyd. Anna Grześkowiak-Krwawicz, Dominique Triaire, Institut d'études slaves, Sociéte historique et littéraire polonaise, Paris 2012.

Stanisław Poniatowski i Maurycy Glayre. Korespondencja dotycząca rozbiorów Polski, cz. 1, wyd. Eugeniusz Mottaz, [wydawnictwo] A.T. Jezierski, Warszawa 1901.

Szczygielski Wacław, Krasiński Adam, PSB, t. 15, Wrocław-Warszawa-Kraków 1970, s. $160-166$.

Szczygielski Wacław, Lubomirski Marcin, PSB, t. 18, Wrocław-Warszawa-Kraków 1973, s. 34-38.

Szczygielski Wacław, Potkański Antoni, PSB, t. 27, Wrocław-Warszawa-Kraków 1973, s. 721.

Szczygielski Wacław, Potocki Józef, PSB, t. 28, Wrocław-Warszawa-Kraków 19841985, s. 73-76.

Szybiak Irena, Ignacy Jakub Massalski, PSB, t. 20, Wrocław-Warszawa-Kraków 1975, s. $135-139$.

Ugniewski Piotr, Media i dyplomacja. „Gazette de France” o sejmie rozbiorowym 17731775, DiG, Warszawa 2006.

Urzędnicy podlascy XIV-XVIII wieku. Spisy, oprac. Ewa Dubas-Urwanowicz [et al.], Biblioteka Kórnicka, Kórnik 1994 (Urzędnicy dawnej Rzeczypospolitej XII-XVIII wieku. Spis, t. 8).

Vetera monumenta Poloniae et Lithuaniae gentiumque finitimarum historiam illustrantia. Maximam partem nondum edita ex tabularis Vaticanis deprompta collecta ac serie 
chronologica disposita, t. 4: Ab Innocentio PP. XII. usque ad Pium PP. VI. 1697-1775, cz. 2, wyd. Augustino Theiner, Typis Vaticanis, Romae 1864.

Zakrzewski Andrzej B., Sejmiki Wielkiego Księstwa Litewskiego XVI-XVIII w. Ustrój i funkcjonowanie: sejmik trocki, Liber, Warszawa 2000.

Zielińska Zofia, Ogiński Andrzej, PSB, t. 23, Wrocław-Warszawa-Kraków 1978, s. 597599.

Носов Борис В., Установление российского господства в Речи Посполитой. 17561768 г2., Индрик, Москва 2004.

Biogram: Piotr Skowroński, ukończył z wyróżnieniem studia magisterskie w Instytucie Historycznym Uniwersytetu Warszawskiego, doktorant w IH PAN, adiunkt w Dziale Badań Naukowych Muzeum Łazienki Królewskie; zajmuje się historią polityczną Rzeczypospolitej w drugiej połowie XVIII w.; kontakt: p.skowronski@ lazienki-krolewskie.pl. 